NBER WORKING PAPER SERIES

\title{
THE ECONOMIC VALUE OF CULTURAL DIVERSITY: EVIDENCE FROM US CITIES
}

\author{
Gianmarco Ottaviano \\ Giovanni Peri \\ Working Paper 10904 \\ http://www.nber.org/papers/w10904 \\ NATIONAL BUREAU OF ECONOMIC RESEARCH \\ 1050 Massachusetts Avenue \\ Cambridge, MA 02138 \\ November 2004
}

We are grateful to Alberto Alesina, Richard Arnott, David Card, Liz Cascio, Masa Fujita, Ed Glaeser, Vernon Henderson, Eliana LaFerrara, David Levine, Doug Miller, Enrico Moretti, Dino Pinelli, Michael Storper, Matt Turner as well as workshop participants at FEEM Milan, RSAI Philadelphia, UBC Vancouver and UC Berkeley for helpful discussions and suggestions. We thank Elena Bellini for outstanding research assistance. Ottaviano gratefully acknowledges financial support from Bocconi University and FEEM. Peri gratefully acknowledge financial support form UCLA International Institute. Errors are ours. The views expressed herein are those of the author(s) and not necessarily those of the National Bureau of Economic Research.

(C) 2004 by Gianmarco Ottaviano and Giovanni Peri. All rights reserved. Short sections of text, not to exceed two paragraphs, may be quoted without explicit permission provided that full credit, including $\odot$ notice, is given to the source. 
The Economic Value of Cultural Diversity: Evidence from US Cities

Gianmarco Ottaviano and Giovanni Peri

NBER Working Paper No. 10904

November 2004

JEL No. O4, R0, F1

\title{
ABSTRACT
}

What are the economic consequences to U.S. natives of the growing diversity of American cities?

Is their productivity or utility affected by cultural diversity as measured by diversity of countries of birth of U.S. residents? We document in this paper a very robust correlation: US-born citizens living in metropolitan areas where the share of foreign-born increased between 1970 and 1990, experienced a significant increase in their wage and in the rental price of their housing. Such finding is economically significant and survives omitted variable bias and endogeneity bias. As people and firms are mobile across cities in the long run we argue that, in equilibrium, these correlations are consistent only with a net positive effect of cultural diversity on productivity of natives.

\author{
Gianmarco I.P. Ottaviano \\ Department of Economics \\ University of Bologna \\ Strada Maggiore 45 \\ 40125 Bologna, Italy \\ ottavian@economia.unibo.it \\ Giovanni Peri \\ Department of Economics \\ University of California, Davis \\ One Shield Avenue \\ Davis, CA 95616 \\ and NBER \\ gperi@ucdavis.edu
}




\section{Introduction}

Since the 1965 amendments to the Immigration and Nationality Act immigration into the United States has been on the surge. In particular, during the eighties and nineties, the trend has been accelerating. As a consequence, during the last thirty years foreign born residents of the United States have increased substantially as a share of total population. Similarly, other industrialized countries (such as Europe and Australia) have recently experienced rising pressures from immigrants. This phenomenon has spurred a heated policy debate and galvanized academic interest.

There is a large and growing body of empirical literature on the consequences of migration (see, among others Borjas 1994, 1995, 1999, 2003; Borjas, Freeman and Katz,1997; Boeri, Hanson and McCormick, 2002; Card 1990, 2001; Card and Di Nardo, 2000). Such literature, however, has disproportionately focussed on one particular aspect of this issue: the impact of low-skilled immigrants on US workers considering, in general, the short and medium run. Our work takes a different angle. Rather than studying the short-run effects of new immigrants on the receiving country in a classic model of skill supply and demand, we consider a simple multi-city model of production and consumption and we ask what is the economic value of the 'diversity' that the foreign born bring to each city. Foreign born are different from US born in their skills and abilities and therefore could be valuable factors in the production of differentiated goods and services. As different US cities attract very different shares of foreign-born we can learn about the value of such 'diversity' from the long-run equilibrium distribution of wages and prices across cities. In the rest of the paper, the term 'cultural diversity' will be used in reference to diversity of countries of birth (rather than in ethnicity or ancestry characteristics) and will be measured by an index of 'plurality' of countries of origin.

Diversity over several dimensions has been considered by economists as valuable in consumption and production. Jacobs (1969) attributes the success of cities to their industrial diversity. Quigley (1998) and Glaeser et al. (2001) identify the diversity of available services and consumption goods as one of the attractive features of cities. Florida (2002a, 2002b) stresses the importance of diversity in creative professions such as research and development and high tech. More generally, Fujita et al (1999) use 'love of variety' in preferences and technology as the building block of their theory of spatial development: production of a larger variety of goods and services in a location increases productivity and utility of people living in that location.

Against this background, we conjecture that cultural diversity may very well be an important aspect of urban diversity with consequences on local production and/or consumption. ${ }^{1}$ The aim of this paper is to test such conjecture by quantifying the value of cultural diversity to US-born people. Who can deny that Italian restaurants, French beauty shops, German breweries, Belgian chocolate stores, Russian ballets and Indian tea

\footnotetext{
${ }^{1}$ An economically oriented survey of the pros and cons of ethnic diversity is presented by Alesina and La Ferrara (2003).
} 
houses constitute valuable consumption amenities inaccessible to Americans were not for their foreign-born residents? Similarly the skills and abilities of foreign-born workers and thinkers may complement those of native workers and thus boost problem solving and efficiency in the workplace. ${ }^{2}$ Cultural diversity, therefore, may increase consumption variety and improve the productivity of natives. On the other hand, natives may not like to live in a multicultural environment in so far as this may endanger their own cultural values. Moreover, intercultural frictions may reduce their productivity and foreign born workers may be perceived to displace their jobs. Cultural diversity would, then, decrease both the utility and the productivity of natives.

We focus on 160 major metropolitan areas in the US, for which we can construct consistent data between 1970 and 1990. We use the 'index of fractionalization' by countries of birth of city residents in order to measure cultural diversity across 160 cities. Such index measures the probability that, in any one city, two individuals chosen at random were born in different countries. Cities entirely populated by US-born individuals have an index of fractionalization equal to 0. If, on the other extreme, each individual in a city was born in a different country the index would equal one. US cities cover a wide range in this measure from 0.02 (Cleveland) to 0.58 (Los Angeles). As US-born people are highly mobile across US cities, following Roback (1982) we develop a model of 'open cities' that allows us to use the observed variations of wages and rents of US-born workers to identify the production and consumption value associated with cultural diversity. In particular, we estimate two regressions in which cultural diversity, measured as 'fractionalization' affects the average wage received and the average rent paid by the US-born workers. Our main finding is that, on average, cultural diversity has a net positive effect on productivity of US-born citizens because it is positively correlated to the average wage received and to the average rent paid by US-born individuals. This partial correlation survives the inclusion of many variables that proxy productivity and amenity shocks across cities.

A key concern in interpreting these correlations as causal effects from diversity to wages and rents is a potential endogeneity bias. Cities may experience increase in average wages, due to economic growth, and attract immigrants thus witnessing an increase in their diversity as well (this hypothesis is often referred to as 'boom cities'). If this were the true story, the measured impact of diversity on wages and rents would be upwardly biased. To tackle this problem, we propose two sets of instruments. First, we observe that the stocks and flows of immigrants tend to be larger in cities that are closer to important 'gateways' into the US. Differently, the stocks of native born and their changes over time are much less dependent on the proximity to these gateways. Therefore, we propose to use the distance of a city from the main gateways into

\footnotetext{
${ }^{2}$ The anedoctical evidence of the contribution of foreign born to 'big thinking' in the US is quite rich. One striking example is the following. In the last ten years, out of the 47 US-based Nobel laureates in Chemistry, Physics and Medicine, 25 per cent (14 laureates) were not US-born. During the same time period the share of foreign-born in the general population was on average only 8 per cent. From our perspective, such example is interesting because research in hard sciences is typically based on large team work.
} 
the US to instrument the change in cultural diversity. Such distance should be weakly correlated with other determinants of wages and rents during the same period. Alternatively, we construct an instrument building on the fact that foreigners tend to settle in 'enclaves' where other people from their country already live (Winters at al., 2001; Munshi, 2003). Following Card (2002) and Saiz (2003b) we construct the 'predicted' change in the number of immigrants from each country in each city during the observed period. The predicted change is based on the actual shares of people from each country in each city at the beginning of the period and the total immigration rate from each country of origin to the US during the whole period. By construction the 'predicted' change does not depend on any city-specific shock during the observed period. Both instruments should reduce the severity of the endogeneity bias. The associated results confirm the existence of a significant positive effect of diversity on the wages and the rents of US-born workers.

The rest of the paper is organized as follows. Section 2 reviews the literature on the economic consequences of cultural diversity. Section 3 introduces our dataset and surveys the main stylized facts. Section 4 develops the theoretical model that is used to design and interpret our estimation strategy. Section 5 presents the results from the basic estimation, checks their robustness and tackles the issue of endogeneity. Section 6 discusses the results and concludes.

\section{Literature on Diversity}

Cultural diversity is a broad concept that has attracted the attention of economist and social scientists. The applied 'labor' literature has analyzed ethnic diversity and ethnic 'segregation' in the US, as well as its impact on economic discrimination and the achievements of minorities ${ }^{3}$. The present paper does not focus on this aspect of cultural diversity: we control for black-white composition issues but we never focus on them.

More closely related to our analysis is the literature on the impact of immigration on the US labor market. Several contributions by George Borjas (notably Borjas,1994, 1995, 1999 and 2003) focus on the issue of new immigrants into the US as a whole, and their effect on native workers. Similarly, important contributions by David Card (notably, Card, 1990; Butcher and Card 1991; Card and Di Nardo, 2000; Card, 2001) analyze the reactions of domestic workers and their wages to inflows of new immigrants by exploiting the geographic variation of immigration rates and wages within the US These contributions do not seem to achieve a consensus view either on the effect of new immigrants on wages of domestic workers (which seems small except, possibly, for very low skill levels) or on the effect of new immigrants on the migration behavior of domestic workers. Recently, evidence of a positive effect of immigrant inflows on rents in cities has

\footnotetext{
${ }^{3}$ Notable examples are Card and Krueger (1992), (1993), Cutler and Glaeser (1997), Eckstein and Wolpin (1999), Mason (2000).
} 
been provided by Saiz (2003a,b). All these studies share some common features especially in terms of their methodological approach. They all focus on the impact of new immigrants in the short run (within years) and use a classic framework of labor demand-supply to analyze the effects. They assume that immigrant and domestic workers, within a skill group, are homogeneous so that immigration is a shift of labor supply, which affects local wages (rents) more or less depending on the mobility of domestic workers. Our approach takes a rather different stand. We consider that being 'foreign-born' is a feature that differentiates individuals (either new or old immigrants) in terms of their attributes and such feature may have positive or negative effects on the utility and the productivity of US-born residents. Moreover, we consider the long-run variations of wages and rents relying on the assumption of perfect mobility of native workers and firms across cities in the long run.

Relevant to our work, several researchers in social sciences have related diversity with urban agglomeration. The functioning and thriving of urban clusters relies on the variety of people, factors, goods and services within them. An example is given by urban studies. Jacobs (1969) sees economic diversity as the key factor of a city's success. Sassen (1994) studies 'global cities' - such as London, Paris, New York, and Tokyo - and their strategic role in the development of activities that are central to world economic growth and innovation. A key feature of these cities is the cultural diversity of their populations. Similarly, Bairoch (1998) sees cities and their diversity as the engine of economic growth. Such diversity, however, has been mainly investigated in terms of a diversified provision of consumers' goods and services as well as productive inputs (see, e.g., Quigley, 1998; Glaeser et al., 2001). In his work at the interface between sociology and economics, Richard Florida (2003a), (2003b) argues that 'diverse' and tolerant cities, are more likely to be populated by creative people and to attract industries such as high tech and research that rely on creativity and innovative ability. The positive 'production value' of diversity has also been stressed by the literature on the organization and the management of teams. A standard assumption is that diversity leads to more innovation and creativity because diversity implies different ways of framing problems, a richer set of alternative solutions, and therefore higher quality decisions. Lazear (1999) provides an attempt to model team interactions. He defines the 'global firm' as a team whose members come from different cultures or countries. Combining workers who have different cultures, legal systems, and languages imposes costs on the firm that would not be present if all the workers were similar. However, complementarity between workers, in terms of skills, offsets the costs of cross-cultural interaction. ${ }^{4}$

Finally, several studies in political economics have looked at the historical effects of cultural and ethnic diversity on the formation and the quality of institutions. The traditional wisdom (confirmed by Easterly and

\footnotetext{
${ }^{4}$ Fujita and Berliant (2004) model 'assimilation'as a result of team work: the very process of cooperative knowledge creation reduces the heterogeneity of team members through the accumulation of knowledge in common. In this respect, a perpetual reallocation of members across different teams may be necessary to keep creativity alive.
} 
Levine, 1997) used to be that more fragmented (i.e. diverse) societies promote more conflicts and predatory behavior, and generate less growth. However, recent studies have questioned that logic by showing that higher ethnic diversity is not necessarily harmful to economic development (see, e.g., Lian and Oneal, 1997). Collier (2001) finds that, as long as their institutions are democratic, fractionalized societies have better economic performance in the private sector than more homogenous ones. Framed within efficient institutions diversity could be an asset for society.

\section{Cultural Diversity, Wages and Rents}

The question we are interested in is: What is there in cultural diversity for the US-born people ? Do they benefit or loose from the presence of foreign-born? How do we measure such benefits or costs?

We are able to extract interesting insights on these questions by analyzing the wage and rent distributions across cities and assuming that such distributions are the equilibrium outcome of economically motivated choices. Workers and firms are mobile across cities and can choose their location in the long run to take advantage of any opportunity arising from productivity and price differentials. As people respond to changes in the local working and living environment of cities, the wage and rent variations that we observe in the long run should reflect a spatial equilibrium: workers and firms are indifferent among alternative locations as they have eliminated any systematic difference in indirect utility and profits through migration. Before formalizing these ideas in Section 4, we put our theoretical analysis into context by introducing our measure of cultural diversity (Section 3.1) and by establishing the main stylized facts about wages, rents and diversity in US cities (Section 3.3).

\subsection{Data and Diversity Index}

Data at the Metropolitan Statistical Area (MSA) level for the United States are available from different sources. We use mostly the Census Public Use Microdata Sample (PUMS) for year 1970 and 1990 in order to calculate wages and rents for specific groups of citizens in each MSA. We use the 1/100 sample from the 15\% PUMS of 1970 and the 5\% PUMS for 1990. We also use data from the 'County and City Data Book' from several years in order to obtain some aggregate variables such as employment, income, population, spending on local public goods. We consider 160 Standard MSA's that could be consistently identified in each census year. Our dataset contains around 1,200,000 individual observations for 1990, and 500,000 for 1970. We use these to construct aggregate variables and indices at the MSA level. The reason for focusing on metropolitan areas is twofold. First, they constitute closely connected economic units within which interactions are intense. Second, they exhibit a higher degree of diversity than non-urban areas because 
immigrants traditionally settle in large cities.

We measure the average wage of native workers in an MSA using the yearly wage of white US-born male residents between 40 and 50 years of age. We denote by $\bar{w}_{U S, c, t}$ the resulting average wage for city $c$ in year $t$. This is affected neither by composition effects nor distorted by potential discrimination factors (across genders or ethnicity) and by life-cycle considerations. It is therefore a good proxy of the average wage of US-born workers in the city and it is comparable across census years. The correlation between $\bar{w}_{U S, c t}$ and the degree of diversity of a city comes only through the equilibrium effect of diversity on labor demand and supply of native workers. As measure of the average land rent in a MSA we use the average monthly rent paid per room (i.e., the monthly rent divided by the number of rooms) by white US-born male residents of working age $(16-65)^{5}$. We denote such measure (for city $c$ in year $t$ ) with $\bar{r}_{U S, c t}$.

Turning to our key explanatory variable, our measure of cultural diversity considers the country of birth of people as defining their cultural identity. Foreign born residents have always been an important part of the US population and their share has grown in the past decades. In 1970, they constituted 4.8 percent of the total population while in 1990 they reached 8 percent and kept on growing afterwards. Our measure of cultural diversity is the so called 'index of fractionalization' (henceforth, simply 'diversity index'), routinely used in the political economics literature. Such index has been popularized in cross-country studies by Mauro (1995) and largely used thereafter. The index is simply the probability that two randomly selected individuals in a community belong to different groups. It accounts for the two main dimensions of diversity, i.e., 'richness' (number of groups) and 'evenness' (balanced distribution of individuals across groups) ${ }^{6}$. Specifically, we use the variable $C o B$ (Country of Birth of a person) to define the cultural identity of each group. The diversity index is defined as:

$$
d i v_{c t}=1-\sum_{i=1}^{M}\left(C o B_{i}^{c}\right)_{t}^{2}
$$

where $\left(C o B_{i}^{c}\right)_{t}$ is the share of people born in country $i$ among the residents of city $c$ in year $t$. This index reaches its maximum value 1 when there are no individuals born in the same country, and its minimum value 0 when all individuals are born in the same country.

The 1970 and 1990 PUMS data report the country of birth of each individual. We consider as separate groups each country of origin of migrants contributing at least 0.5 percent of the total foreign-born population working in the US. The other countries of origin are gathered in a residual group. Such choice implies that we consider 35 countries of origin in 1970 as well as in 1990. These groups constitute 92 percent of all foreignborn immigrants while the remaining 8 percent are merged into one group. The complete list of countries for

\footnotetext{
${ }^{5}$ The housing market is less segmented by skills than the labor market.Therefore we use a larger age-range in order to calculate average rents.

${ }^{6}$ Despite differences that may seem notable at first sight, most statistical measures of diversity are either formally equivalent or at least highly correlated when run on the same data set. See Maignan et al (2003) for details.
} 
each census year is reported in the data appendix and the largest 15 of these groups are reported in Table 1. As the table shows, between 1970 and 1990, the origin of migrants has become increasingly polarized towards Mexican immigrants; the share of foreign born, however, has increased as well so that overall the diversity index has increased. As to the main countries of immigration, we note the well known shift from European countries towards Asian and Latin American countries.

\subsection{Diversity Across US Cities}

Table 2 shows the percentage of foreign-born and the diversity index for a representative group of metropolitan areas in year 1990. To put into context the extent of diversity across US cities, their diversity index can be compared with the cross-country values of the index of linguistic fractionalization reported by the Atlas Narodov Mira and published in Taylor and Hudson (1972) for year 1960. Such values have been largely used in the growth literature (see, e.g., Easterly and Levine, 1997, and Collier, 2001). As foreign-born immigrants normally use their country's mother tongue at home and in turn this signals their country's cultural identity, our diversity index captures cultural and linguistic fragmentation for different US cities just as that index does for different countries in the world. The comparison is instructive. Diversified cities, such as New York or Los Angeles, have diversity indices between 0.5 and 0.6, which are comparable to the values calculated for countries such as Rhodesia (0.54), which is often disrupted by ethnic wars, or Pakistan (0.62), which also features a problematic mix of conflicting cultures. More homogenous cities, such as Cincinnati and Pittsburgh, exhibit a degree of fractionalization equal to 0.05 , which is the same as that of very homogenous European countries, such as Norway or Denmark in the sixties. Between these two extremes US cities span a range of diversity that is about two thirds of the range spanned by countries in the world. Table 2 also shows that, even though people born in Mexico constitute an important group in many cities, the variety of countries of origin of residents of US cities was still remarkable in 1990. Finally we note that there is a very high correlation between the diversity index and the share of foreign born in a city. The main reason for an American city being 'diverse' is the large percentage of foreign born living there, rather than the high degree of diversity within the foreign born.

\subsection{Stylized Facts}

The key empirical finding of our paper is readily stated: ceteris paribus, US-born workers living in cities with higher cultural diversity are paid, on average, higher wages and pay higher rents than those living in cities with lower cultural diversity. In section 5 we show that this correlation not only survives the inclusion of several other control variables but it is likely to be the result of causation running from diversity to wages 
and rents.

We report here the correlation between the change of the diversity index for the 1970-90 period, $\Delta\left(\operatorname{div}_{c t}\right)$, and the percentage change in the wage of the US-born, $\Delta \ln \left(\bar{w}_{U S, c}\right)$, or the percentage change in rents paid by the US-born, $\Delta \ln \left(\bar{r}_{U S, c}\right)$ in 160 metropolitan areas. The effect of fixed city-characteristic such as their location or geographic amenities, is eliminated by differencing. Figure 1 and 2 show the scatter-plots of these partial correlation and report the OLS regression line. Cities whose diversity increased more than the average, during the twenty years considered, (such as Jersey City, Los Angeles, San Francisco or San Jose), have also experienced larger than average wage increase for their US-born residents. Similarly they also experienced a larger than average increase in rents. The OLS coefficient estimates imply that a city experiencing an increase of 0.09 in the diversity index (such as Los Angeles did) would experience an associated increase of 11 percentage points in the average wage and of 17.7 percentage points in the average rent paid by US-born residents, relative to a city whose diversity index did not change at all (such as Cleveland).

\section{Theoretical Framework}

\subsection{The Model}

To structure and interpret our empirical investigation, we develop a stylized model in which 'diversity' affects both the productivity of firms and the satisfaction of consumers through a localized effect. Both the model and the identification procedure build on Roback (1982).

We consider an open system of a large number $N$ of non-overlapping cities, indexed by $c=1, \ldots, N$. There are two factors of production, labor and land. We assume that intercity commuting costs are prohibitive so that for all workers the city of work and residence coincides. We also ignore intra-city commuting costs, which allows us to focus on the intercity allocation of workers.

The overall amount of labor available in the economy is equal to L. It is inelastically supplied by urban residents and, without loss of generality, we choose units such that each resident supplies one unit of labor. Accordingly, we call $L_{c}$ the number of workers employed and resident in city $c$. Workers are all identical in terms of attributes that are relevant for market interactions. However, they differ in terms of nonmarket attributes, which exogenously classifies them into $M$ different groups ('cultural identities') indexed by

$i=1, \ldots, M$. Hence, calling $L_{i}$ the overall number of workers belonging to group $i$, we have $\sum_{i=1}^{M} L_{i}=L$. In each city cultural diversity $d_{c}$, measured in terms of the number ('richness') and relative sizes $L_{i c}$ ('evenness') of resident groups, enters both production and consumption as an effect that, in principle, can be positive or negative. To establish the existence and the sign of such effect is the final aim of the paper. Land is fixed 
among cities. It is nonetheless mobile between uses within the same city. We call $H_{c}$ the amount of land available in city $c$. As to land ownership, we assume that the land of a city is owned by locally resident landlords. ${ }^{7}$

Preferences are defined over the consumption of land $H$ and a homogeneous good $Y$ that is freely traded among cities. Specifically, the utility of a typical worker of group $i$ in city $c$ is given by:

$$
U_{i c}=A_{U}\left(d_{c}\right) H_{i c}^{1-\mu} Y_{i c}^{\mu}
$$

with $0<\mu<1$. In $(2) H_{i c}$ and $Y_{i c}$ are land and good consumption respectively while $A_{u}\left(d_{c}\right)$ captures the 'utility effect' associated with local diversity $d_{c}$. If the first derivative $A_{u}^{\prime}\left(d_{c}\right)$ is positive, diversity can be seen as a local amenity; if negative as a local disamenity.

We assume that workers move to the city that offers them the highest indirect utility. Given (2), utility maximization yields:

$$
r_{c} H_{i c}=(1-\mu) E_{i c}, p_{c} Y_{i c}=\mu E_{i c}
$$

which implies that the indirect utility of the typical worker of group $i$ in city $c$ is:

$$
V_{i c}=(1-\mu)^{1-\mu} \mu^{\mu} A_{u}\left(d_{c}\right) \frac{E_{i c}}{r_{c}^{1-\mu} p_{c}^{\mu}}
$$

where $E_{i c}$ is her expenditures while $r_{c}$ and $p_{c}$ are the local land rent and good price respectively.

As to production, good $Y$ is supplied by perfectly competitive firms using both land and labor as inputs. The typical firm in city $c$ produces according to the following technology:

$$
Y_{j c}=A_{Y}\left(d_{c}\right) H_{j c}^{1-\alpha} L_{j c}^{\alpha}
$$

with $0<\alpha<1$. In (5) $H_{j c}$ and $L_{j c}$ are land and labor inputs respectively. $A_{Y}\left(d_{c}\right)$ captures the 'productivity effect' associated with local diversity $d_{c}$. It is convenient to capture the effect of diversity as a shift in total factor productivity, $A_{Y}^{\prime}\left(d_{c}\right)$, that is common to all firms in city $c$. This shift could be positive or negative. ${ }^{8}$

Given (5) and perfect competition, profit maximization yields:

$$
r_{c} H_{j c}=(1-\alpha) p_{c} Y_{j c}, w_{c} L_{j c}=\alpha p_{c} Y_{j c}
$$

\footnotetext{
${ }^{7}$ This assumption is made only for analytical convenience. What is crucial for what follows is that the rental income of workers, if any, is independent of locations and, thus, it does not affect the migration choice. The alternative assumptions of absentee landlords or balanced ownership of land across all cities would also serve that purpose.

${ }^{8}$ The contribution of diversity to total factor productivity could stem from imperfect substitutability of different groups as well as from pecuniary or learning externalities. For instance, Ottaviano and Peri (2004a) derive a production function similar to (5) with non tradable intermediates and taste for variety.
} 
which implies marginal cost pricing:

$$
p_{c}=\frac{r_{c}^{1-\alpha} w_{c}^{\alpha}}{(1-\alpha)^{1-\alpha} \alpha^{\alpha} A_{Y}\left(d_{c}\right)}
$$

so that firms make no profits in equilibrium. Given our assumption on land ownership, this implies that aggregate expenditures in the city equal local factor incomes and that workers' expenditures consist of wages only: $E_{i c}=w_{c}$. Since good $Y$ is freely traded, its price is the same everywhere. We choose the good as numeraire, which allow us to write $p_{c}=1 .^{9}$

In a spatial equilibrium there exists a set of prices $\left(w_{c}, r_{c}, c=1, \ldots, N\right)$ such that in all cities workers and landlords maximize their utilities given their budget constraints, firms maximize profits given their technological constraints, factor and product markets clear. Moreover, no firm has an incentive to exit or enter. This is granted by condition (7) that, given our choice of numeraire, can be rewritten as:

$$
r_{c}^{1-\alpha} w_{c}^{\alpha}=(1-\alpha)^{1-\alpha} \alpha^{\alpha} A_{Y}\left(d_{c}\right)
$$

We will refer to (8) as the 'free entry condition'. Finally, in a spatial equilibrium no worker has an incentive to migrate. For an interior equilibrium (i.e., $\left.L_{c}>0 \forall c=1, \ldots, N\right)$ this is the case when workers are indifferent between alternative cities:

$$
V_{i c}=V_{i k}, \forall c, k=0, \ldots, N
$$

We will refer to (9) as the 'free migration conditions'.

To complete the equilibrium analysis we have to determine the spatial allocation of workers $L_{i c}$. This is achieved by evaluating the implications of market clearing for factor prices. Specifically, given $L_{c}=\sum_{j} L_{j c}$ and $Y_{c}=\sum_{j} Y_{j c}$, (6) imply $w_{c} L_{c}=\alpha p_{c} Y_{c}$. Given $H_{c}=\sum_{j} H_{j c}+\sum_{i} H_{i c}$, (6) and (3) imply $\mu r_{c} H_{c}=$ $(1-\alpha \mu) p_{c} Y_{c}$. Together with $E_{i c}=w_{c}$ and $p_{c}=1$, those results can be plugged into (4) to obtain:

$$
V_{i c}=\mu\left(\frac{1-\mu}{1-\alpha \mu}\right)^{1-\mu}\left(\frac{H_{c}}{L_{c}}\right)^{1-\alpha \mu} A_{U}\left(d_{c}\right)\left[A_{Y}\left(d_{c}\right)\right]^{\mu}
$$

Substituting (10) into (9) generates a system of equations that can be solved for the equilibrium spatial allocation of workers. In particular, such substitution gives $M(N-1)$ free migration conditions that, together with the $M$ group-wise full-employment conditions $\sum_{c=1}^{N} L_{i c}=L_{i}$, assign $L_{i c}$ mobile workers of each group $i=1, . ., M$ to each city $c=1, \ldots, N$. Constant returns to scale and fixed land ensure that the spatial

\footnotetext{
${ }^{9}$ Anticipating the empirical implementation of the model, by setting $p_{c}=1$ for all cities we are requiring the law-of-one-price to hold for tradable goods and non-tradable goods prices to be reasonably proxied by land rents. This is supported by the large positive correlation between local price indices and land rents at the SMSA level.
} 
equilibrium is unique and has a positive number of workers in every city ('no ghost town'). Then, the composition of the urban community depends on the net impact of diversity on utility and productivity.

\subsection{Identification: Wage and Rent Equations}

To prepare the model for empirical investigation, it is useful to evaluate wages and land rents at the equilibrium allocation. This is achieved by solving together the logarithmic versions of the free entry condition (8) and the free mobility condition (9) that take (4) into account. Specifically, call $v$ the equilibrium value of indirect utility. Due to free mobility of US-born such value is common among cities and, due to the large number of cities, it is unaffected by city-level idiosyncratic shocks. Then, solving (8) and (9) for factor prices gives the 'rent equation':

$$
\ln r_{c}=\frac{\eta_{Y}+\alpha \eta_{U}}{1-\alpha \mu}+\frac{1}{1-\alpha \mu} \ln \left(A_{Y}\left(d_{c}\right)\left[A_{U}\left(d_{c}\right)\right]^{\alpha}\right)
$$

and the 'wage equation':

$$
\ln w_{c}=\frac{(1-\mu) \eta_{Y}-(1-\alpha) \eta_{U}}{1-\alpha \mu}+\frac{1}{1-\alpha \mu} \ln \left(\frac{\left[A_{Y}\left(d_{c}\right)\right]^{1-\mu}}{\left[A_{U}\left(d_{c}\right)\right]^{1-\alpha}}\right)
$$

where $\eta_{Y} \equiv \ln (1-\alpha)^{1-\alpha} \alpha^{\alpha}$ and $\eta_{U} \equiv(1-\mu)^{1-\mu} \mu^{\mu} / v$.

Equations (11) and (12) constitute the theoretical foundations of our empirical analysis. They capture the equilibrium relationship between diversity and factor prices. In the light of Roback (1982), the two equations have to be estimated together in order to identify the effect of diversity on productivity and utility. Consider, for instance, (11) in isolation. A positive correlation between $d_{c}$ and $r_{c}$ is consistent both with a positive effect of diversity on utility $\left(A_{U}^{\prime}\left(d_{c}\right)>0\right)$ or a positive effect of diversity on productivity $\left(A_{Y}^{\prime}\left(d_{c}\right)>0\right)$. Analogously, if one considers (12) in isolation, a positive correlation between $d_{c}$ and $w_{c}$ is consistent with a negative utility effect $\left(A_{U}^{\prime}\left(d_{c}\right)<0\right)$ or positive productivity effect $\left(A_{Y}^{\prime}\left(d_{c}\right)>0\right)$ of diversity. Only the joint estimation of (11) and (12) allows one to establish which effect is indeed dominating. Specifically:

$$
\begin{aligned}
& \frac{\partial r_{c}}{\partial d_{c}}>0 \text { and } \frac{\partial w_{c}}{\partial d_{c}}>0 \text { iff dominant positive productivity effect }\left(A_{Y}^{\prime}\left(d_{c}\right)>0\right) \\
& \frac{\partial r_{c}}{\partial d_{c}}>0 \text { and } \frac{\partial w_{c}}{\partial d_{c}}<0 \text { iff dominant positive utility effect }\left(A_{U}^{\prime}\left(d_{c}\right)>0\right) \\
& \frac{\partial r_{c}}{\partial d_{c}}<0 \text { and } \frac{\partial w_{c}}{\partial d_{c}}<0 \text { iff dominant negative productivity effect }\left(A_{Y}^{\prime}\left(d_{c}\right)<0\right) \\
& \frac{\partial r_{c}}{\partial d_{c}}<0 \text { and } \frac{\partial w_{c}}{\partial d_{c}}>0 \text { iff dominant negative utility effect }\left(A_{U}^{\prime}\left(d_{c}\right)<0\right)
\end{aligned}
$$


Figure 3 provides a graphical intuition of the proposed identification. In the figure $w_{c}$ and $r_{c}$ are measured along the horizontal and vertical axes respectively. Given the utility level $v$ and diversity $d_{c}$, the free entry condition (8) is met along the downward sloping curve, while the free migration condition (9) holds along the upward sloping curve. The equilibrium factor prices for city $c$ are found at the intersection of the two curves. Diversity $d_{c}$ acts as a shift parameter on the two curves: any shock to diversity shifts both curves. An increase in $d_{c}$ shifts (8) up (down) if diversity has a positive (negative) productivity effect and it shifts (9) up (down) if diversity has a positive (negative) utility effect. Thus, by looking at the impact of a diversity shock on the equilibrium wage and rent, we are able to identify the dominant effect of diversity. For example, consider the initial equilibrium $A$ and the new equilibrium $A^{\prime}$ that prevails after a shock to diversity. In $A^{\prime}$ both $w_{c}$ and $r_{c}$ have risen. Our identification argument states that both factor prices rise if and only if an upward shift of (8) dwarfs any shift of (9), i.e., the positive productivity effect dominates.

\section{$5 \quad$ Wage and Rent Regressions}

\subsection{Basic Specifications}

The theoretical model provides us with a consistent framework to structure our empirical analysis. In particular it suggests how to use wage and rent regressions to identify the effect of diversity, considered as a city-characteristic, on productivity and utility of US natives. Our units of observation are the 160 Metropolitan Statistical Areas (MSA's) listed in the Appendix. The years of observation are 1970 and 1990. As an empirical implementation of the wage equation (12), we run the following basic regression:

$$
\ln \left(\bar{w}_{U S, c, t}\right)=\beta_{1}\left(\bar{s}_{U S, c, t}\right)+\beta_{2} \ln \left(E m p l_{c, t}\right)+\beta_{3} d i v_{c, t}+e_{c}+e_{t}+e_{c t}
$$

The average wage of natives in city $c$ in year $t, \bar{w}_{U S, c, t}$, is defined as described in section 3.1. The focal independent variable is $d i v_{c, t}$, which is the diversity index defined in equation (1). The other independent variables are controls. Specifically, $\bar{s}_{U S, c, t}$ measures the average years of schooling for the group of white US-born males aged from 40 to $50 . E m p l_{c, t}$ is total non-farm employment in city $c$ and year $t$. We also include 160 city fixed effects $e_{c}$ and common time-effects $e_{t}$. Finally, $e_{c t}$ is a zero-mean random error term independent from the other regressors.

Under this assumption, the coefficient $\beta_{3}$ captures the equilibrium effect on wages of a change in cultural diversity. However, as discussed in the subsection 4.2, the sign of $\beta_{3}$ cannot be directly interpreted as evidence of any positive effect of diversity on production. Identification, thus, requires to estimate the following parallel rent regression 


$$
\ln \left(\bar{r}_{U S, c, t}\right)=\gamma_{1} \ln (\bar{y})_{U S c, t}+\gamma_{2} \ln \left(P o p_{c, t}\right)+\gamma_{3} d i v_{c, t}+\varepsilon_{c}+\varepsilon_{t}+\varepsilon_{c t}
$$

The average rent of natives $\bar{r}_{U S, c, t}$ in city $c$ in year $t$ is defined as described in section 3.1. The focal independent variable is again the diversity index $d i v_{c, t}$. The other independent variables are controls. Specifically, $(\bar{y})_{c, t}$ is the average yearly income of the group of white US-born males in city $c$ in year $t$, while $P_{o p} p_{c, t}$ is the total population of the city. We control for city fixed effects $\varepsilon_{c}$, a year dummy $\varepsilon_{t}$, and we assume that $\varepsilon_{c t}$ is a zero-mean random error uncorrelated with the regressors. The coefficient $\gamma_{3}$ captures the equilibrium effect of a change in cultural diversity on average city rents. By merging the information on the signs of $\beta_{3}$ and $\gamma_{3}$, we are able to identify the net effect of diversity. We begin by estimating the two basic regressions using least squares, and then we proceed to include further controls and use different estimation methods.

The least squares estimates of the regressions (14) and (15) are reported in Table 3. Specification I shows the basic estimates for the wage equation, while Specification III does the same for the rent equation. After controlling for the returns to schooling, the effect of employment and the fixed effects we find that the diversity index has a positive and very significant effect on wages. Similarly, after controlling for population, income per capita and fixed effects the diversity index has also a positive effect on rents. The estimated coefficients are both statistically and economically significant. An increase of the diversity index by 0.1 (roughly the increase experienced by Los Angeles during the considered period) is associated with a 13\% increase in average wages of US natives and with a $9.5 \%$ increase in rents.

Column II and IV of Table 3 decompose the effect of diversity in two parts. The diversity index can be expressed as the contribution of two factors. First, a city is more diverse if the overall group of foreign-born people is larger. Second, it is more diverse if the foreign-born group is made up of a wider variety of groups. The diversity index can be written as a (non linear) function of the share of foreign-born and a diversity index calculated on foreign born only. We enter these two factors separately in Specifications II and IV in order to analyze their impact on wages and rents, respectively. Let us note that the share of foreign born is, by far, the most important component in determining the variation of the diversity index across cities. It explains, by itself, almost $90 \%$ of the index variation. It is not a surprise, therefore, to find that the share of foreigners is the most important contributor to the effect on wages and rents. An increase in the share of foreign born by 0.25 (experienced by Los Angeles during the considered period) is associated with 14.5\% increase in wages of US natives and a $13.5 \%$ increase in rents. The effect of diversity of foreigners, on the other hand, has a positive impact but only marginally significant. To sum up, diversity has positive and highly significant correlations with both wage $\left(\beta_{3}>0\right)$ and land rent $\left(\gamma_{3}>0\right)$. Such positive correlations can be interpreted as consistent with a dominant positive productivity effect of diversity. 
Before moving to further specifications and robustness checks, let us consider another correlation that reinforces our interpretation of a dominant positive effect of diversity on productivity. The theoretical model makes clear (see (6)) that, in the presence of a positive productivity effect, the increase of diversity in a certain city shifts the local labor demand up, thus raising not only local wages but also local total employment. Differently, a negative utility effect would be associated with higher wages but lower employment. Table 4 reports the correlation between changes in diversity and changes in employment as well as population of US cities between 1970 and 1990. If the labor supply curve had shifted up with labor demand unchanged, that would have caused the observed increase in wages but would have been associated with a decrease in employment. The table shows positive effects of diversity on employment and population, which is consistent with a dominant upward shift of labor demand as expected in the presence of a dominant positive productivity effect.

\subsection{Checks of Robustness}

Our basic specifications for the wage and rent regressions omit several variables that, in principle, could simultaneosly affect local diversity, wages, and rents. In so far as they change over time, the impacts of such omitted variables are not captured by the city fixed effects. This section is devoted to testing whether the estimated effects of diversity are robust to the inclusion of omitted variables. While the list of potential controls is never complete, we include here some important ones for which we can think of plausible stories that could generate the spurious correlation. Table 5 reports the estimated effects of the diversity index (and its components) in the wage equation as we include additional controls. Table 6 presents analogous results for the rent regression.

The positive effect of diversity on the wage of US-born could simply be a result of the foreigners' measurable skills. As the foreign-born residents have different schooling achievements than US-born, then through complementarity or externalities, this feature could be responsible for the effect on wages of the US-born. Specifications (2) in Tables 5 and 6 include the average years of schooling of the foreign-born workers as additional control variable in the wage and rent regressions respectively. While analyzing human capital externalities using average schooling has been common practice (Rauch, 1993; Moretti, 2004), if workers with different schooling levels are imperfect substitutes or if the distribution of their skills matters, then average schooling may not be a sufficient statistic to capture the presence of complementarity or externalities. The estimated effect of diversity is still significant and positive on wages and rents when we include this control. Interestingly, the effect (not reported) of average schooling of the foreign-born on the wages of the US-born is not significant, while it is small and positive on US-born rents. This result tells us that the simple average 
schooling of foreign-born does not capture their 'value'. Their skill distribution may matter as well as the fact that their abilities may be differentiated from those of natives, even at the same schooling level. When decomposing the overall diversity (column 2 and 3 in the tables) we still find a significant and positive effect of the share of foreign born on both rents and wages, while the diversity of foreigners has significant positive impact on wages but not on rents.

Another plausible (but spurious) reason for positive correlations between diversity and wages-rents is that migration may respond to productivity and amenities shocks. In so far as we do not observe these shocks, we are omitting the common underlying cause of wages, rents, and diversity. To address this issue we use two strategies. The first strategy, which we postpone to Section 5.3, tries to identify a variable correlated (or more correlated) with the share of foreign born but not otherwise correlated with shocks to productivity or amenities. Then, it uses this variable as an instrument in the estimation. The second strategy, pursued here, exploits the fact that if shocks to productivity attract workers into a city then this should work for US-born as well as for foreign-born workers. Therefore, if we included the share of US-born citizens in each city coming from out of state (i.e., born in a different state) in the wage and rent regressions, such variable should be correlated with the same local productivity and amenities shocks that attract foreigners. Its inclusion should decrease significantly the estimated coefficients $\beta_{3}$ and $\gamma_{3}$. Moreover, we should find a significant positive correlation between this share and wage-rents of US born. Specification (3) in Tables 5 and 6 include the share of US-born citizens who were born out of state. Its coefficient (not reported) is not significant in either regression, while the effects of diversity and of the share of foreign born on wages and rents are still significantly positive and virtually unchanged. These results suggest that the presence of the foreign born does not simply signal that cities have experienced an unobserved positive shock since that would have attracted both foreign and US-born workers. Interestingly, they also imply that such presence does not simply reveal that boom cities have attracted more talented people as people of similar talent should respond similarly to the same shock.

Some sociologists have advanced the hypothesis that environments that are tolerant towards diversity are more productive and more pleasant to live in. Along these lines Richard Florida (2002a,b) has argued that cities where the number of artists and bohemian professionals is larger are more innovative in high tech sectors. It is likely that part of our correlations may actually depend on this good attitude of cities towards diversity. However, to show that there is something specific to the presence of foreign-born, we include in Specification (4) of Tables 6 and 7 the share of US-born people identifying themselves as 'non-white'. Since we consider only US-born people, such index essentially captures the white-black composition of a city. The coefficients on this variable turn out to be positive in the wage regression (0.20) and negative in the rent regression $(-0.22)$. We may interpret these results as (weak) evidence of the aversion of white US-born 
against living close to large non-white (US-born) communities. The standard errors however (in both cases around 0.2 , make the estimated coefficients not significant. As to the coefficients of the diversity index they are still positive, significant (except in one case for the rent regression), and similar to previous estimates. Thus, in spite of the more ambiguous effect of ethnic diversity, diversity in terms of the country of birth maintains its own importance.

Several public services in US cities are supplied by local governments. Public schools, public health care, and public security are all desirable local services. Therefore, cities whose quality of public services has improved in the period of observation may have experienced both an increase in the share of foreign born (possibly larger users of these services) and a rise in property values. From the County and City Databook we have gathered data on the spending of local government per person in a city and on its breakdown across different categories particularly in education. Specification (5) of Tables 5 and 6 includes overall spending by local government whereas Specification (6) includes spending on education, a very important determinant of the quality of schools. The effect of public spending per person on rents (not reported) is positive in both specifications, however its inclusion does not change the effect of diversity.

If different groups of workers are imperfect substitutes, even among the US natives the average wage of the group of white males 40-50 may be affected by their relative supply. While there is no clear reason to believe that the relative size of this group is correlated with the diversity of a city, it may be appropriate to control for the (log) employment of this group and not just for total employment. The corresponding results are reported in Specification (7) of Table 5, which shows that the coefficient of the diversity index is still equal to 1.3. Specification (7) of Table 6 considers instead the group of white US-born males as potentially competing for similar housing and therefore it includes the log of their population together with that of total population. This specification is very similar to Specification (4), which includes the share of non-whites and gives similar estimates: 0.69 for the coefficient of diversity and 0.50 for the one on the share of foreign born.

The most conservative check is Specification (8) which includes together all the controls that are included separately in the specifications (2) to (7). Reassuringly, the coefficient on the share of foreign-born is still positive, very stable, and significant in both regressions. The coefficient on the diversity index is also positive, very stable, and significant in the wage regression while it turns out not significant in the rent regression. ${ }^{10}$

In Specifications (9) and (10) of Tables 5 and 6 we push our data as far as they can go. Specification (9) estimates the wage and rent regressions excluding the three states with the highest shares of foreignborn, namely California, New York and Florida. The aim is to check whether few highly diverse cities in those states generate the correlations of diversity with wages and rents. This is not the case. In the wage

\footnotetext{
${ }^{10}$ Some authors (see, e.g., Sivitanidou and Wheaton, 1992) have argued that the institutional constraints on land use ('zoning') can affect land values. Thus, higher property values may be associated with more efficient institutional constraints in the presence of market failures. This effect, however, should be captured by our local public goods measures.
} 
regression the coefficient on diversity decreases somewhat but remains both positive and significant. In the rent equation the coefficient on diversity becomes larger but less precisely estimated. In general, however, there is no evidence that in the long run the effect of diversity is different for high immigration states and low immigration states.

In Specification (10), rather than the panel with city and year dummies, we use instead the differences of the basic variables between 1990 and 1970. We also include state fixed effects to control for differences in state-specific growth rates of wages and rents. In so doing we identify the effects of diversity on wages and rents through the variation across cities within states. This is an extremely demanding specification as we are probably eliminating most of the variation needed to identify the results by estimating 48 dummies using 160 observations. Remarkably, the positive effect of diversity on productivity still stands and its point estimate is similar to those of previous specifications. The effect of diversity on rents, however, while still positive, is no longer significant.

We perform one more check in Specification (11) of Table 5 in order to verify that our results survive when we consider groups that are more mobile across cities than the 40 -to-50 years old workers. We estimate the wage equation using the average wage of white US-born males between 30 and 40 years of age. The coefficients on diversity and the share of foreign born are still significantly positive, equal to 1.14 and 0.60 , respectively.

Finally, since our theoretical model shows that in equilibrium wages and rents are simultaneously determined (see equations (11) and (12)) implying correlation between the unobservable idiosyncratic shocks to wages $\varepsilon_{c t}$, and rents $e_{c t}$, we can increase the efficiency of our estimates by explicitly accounting for such correlation and estimating a seemingly unrelated regression (SUR). While OLS estimates are still consistent and unbiased even when $\varepsilon_{c t}$ and $e_{c t}$ are correlated, SUR estimates are more efficient. The estimated coefficients are virtually identical to those estimated in Table 5 and 6 . For sake of brevity we do not report the results here. ${ }^{11}$

In summary, most wage and rent regressions yield positive and significant coefficients for both the diversity index and the share of foreign born. The diversity of foreign born also has a positive effect but such effect is less often significant. We do not find any specification such that the coefficients on the diversity variable are simultaneously not significant in both the wage and the rent regressions. Moreover each single estimate delivers positive estimates of diversity on wages and rents of natives. Therefore, our identification (13) allows us to conclude that no specification contradicts the hypothesis of a positive productivity effect of diversity.

\footnotetext{
${ }^{11}$ The results of SUR estimation are available in Ottaviano and Peri (2004b).
} 


\subsection{Endogeneity and Instrumental Variables}

Short of a randomized experiment in which diversity across cities is changed exogenously and randomly, we cannot rest assured that our correlations reveal any causal link from diversity to wages and rents. Nonetheless, some steps towards tackling the endogeneity problem can be taken using instrumental variables (IV) estimation. Our instruments should be correlated with the change in diversity of cities in the 1970-1990 and not otherwise correlated with changes in wages and rents. We propose two instruments satisfying these properties. Both exploit the fact that, independently from the characteristics of any single city, overall immigration to the US increased significantly between 1970 and 1990.

\subsubsection{Gateways into the US}

To construct the first instrumental variable we build on the fact that immigrants tend to enter the US through few 'Gateways', or through the border. As a consequence, the total number of foreign born in city $c$ at time $t, F_{c t}$, as well as the total increase in foreign born in city $c, \Delta F_{c t}$, depends negatively on the distance from the closest gateway. As long as the total number of US-born residents in a city, $N_{c t}$, does not depend (or depends to a lesser extent) on such distance we have that both the share of foreign born, $F_{c t} /\left(F_{c t}+N_{c t}\right)$, and its change are negatively correlated with the distance from the immigration gateways into the US.

Each year the US Office of Tourism publishes the percentage of inbound travellers by point of entry. Looking at the data for the eighties, we see that the three main gateways were New York, Miami, and Los Angeles. About 30 percent of the foreign (immigrant and non-immigrant) travellers entered the US through the airports and ports of these cities. Moreover, due to networks, costs of travelling, and costs of spreading information, immigrants were more likely to settle in cities closer to these gateways. A similar argument can be made for Canadian and Mexican immigrants. For them, it seems reasonable to assume that the US borders with their own countries constitute the natural place of entry into the US. Thus, as before, cities at a smaller distance from the borders were more likely to receive Canadian and Mexican immigrants during the 1970-1990 period.

These considerations suggest the use of the overall distance of a city from the main gateways into the US (New York, Miami, Los Angeles and the US borders with Canada and Mexico) to instrument its diversity index (heavily dependent on the share of foreign-born). Such distance should be negatively correlated with diversity but not with shocks to wages and rents.

This strategy is open to critique. If the three main gateways (New York, Miami, and Los Angeles) experienced above average growth in the time period considered, then positive spillover effects on nearby cities could attract foreigners. As a result, the distance of a city from the gateways would be negatively 
correlated with the increases in wages and rents because of a 'boom city' effect and not because of a positive effect of diversity. To see whether this is a relevant concern in our data set, we have calculated employment growth for the three cities in the period of observation. It turns out that in each of those three cities employment growth was actually lower than the average for US metropolitan areas. Population growth was also below average in New York and Los Angeles, while it was above average in Miami. Overall, the three gateways into the US did not really show the features of 'boom cities'. However, since Miami still exhibited better performance than the other two, we have also used only distances from New York and Los Angeles as instruments: the results are virtually unchanged.

Tables 7 and 8 report the first and second stage estimates of the described IV regressions using wages and rents, respectively, as the dependent variable. Column 1 of tables 7 and 8 shows the basic specification; Column 2 includes 48 state fixed-effects; Column 3 excludes all the coastal cities from the regression to make sure that the results are not simply driven by the difference in shares of foreigners and productivity between the coast and the inland. The first stage regressions confirm that our excluded instruments are excellent: in the first stage they explain 50 percent of the variation in diversity which is orthogonal to the other regressors. Including state effects, more than $20 \%$ of the residual variation in diversity is still explained by the instruments. This means that in cities located far from the gateways into the US, diversity grew significantly less than in cities close to them.

The estimates of Specification 1 (Table 7 and 8 ) confirm that the effect of diversity on wages and rents is positive and large. The estimated coefficient is significant and very large for wages (1.55) while for rents it is large (1.60) but significant only at the $15 \%$ level. Moreover, the IV estimates are somewhat higher than the OLS ones, hence we are reassured that no significant (endogeneity-driven) downward OLS bias exists. For the wage regressions we obtain a positive and significant effect of diversity when controlling for 48 state fixed effects (Specifications 2, Table 7) and when we eliminate coastal cities (Specifications 3, Table 7). The last specification has quite large standard errors, but it certainly reinforces our thesis that foreign-born have a positive effect in non-coastal cities as well. As to the rent regressions, the share of foreigners has a positive and significant effect in Specification 3 of Table 8 (excluding coastal cities). When we include state dummies (Specification 2, Table 8) the effect of foreign-born is not significant any longer (but still positive) as also found in the corresponding OLS estimates.

\subsubsection{Shift-Share Methodology}

A second instrumental variable, independent of idiosyncratic city shocks, could be constructed using the 'shift-share methodology' used by Card (2001) and, more recently, applied by Saiz (2003b) to migration in MSA's. Immigrants tend to settle where other immigrants from the same country already reside (immigration 
enclaves). Therefore, we can use the share of residents of an MSA in 1970 for each country of birth and attribute to each group the growth rate of that group within the whole US population in the 1970-1990. In so doing we compute the predicted composition of the city based on its 1970 composition and we attribute to each group the average growth rate of its share in the US population. Once we have constructed these 'predicted' shares for 1990 we can calculate a 'predicted' diversity index for each city in 1990.

Let us use the notation introduced in section 3.1 where $\left(C o B_{i}^{c}\right)_{t}$ denotes the share of people born in country $i$ among the residents of city $c$ in year $t$. Hence, $\left(C o B_{i}\right)_{t}=\sum_{c}\left(C o B_{i}^{c}\right)_{t}$ is the share of people born in country $i$ among US residents in year $t$. Between 1970 and 1990 its growth rate is:

$$
\left(g_{i}\right)_{1970-90}=\left[\left(C o B_{i}\right)_{1990}-\left(C o B_{i}\right)_{1970}\right] /\left(C o B_{i}\right)_{1970}
$$

This allows us to calculate the 'attributed' share of people born in country $j$ and residing in city $c$ in 1990 as:

$$
\left(\widehat{C O B}_{i}^{c}\right)_{1990}=\left(C o B_{i}^{c}\right)_{1970}\left[1+\left(g_{i}\right)_{1970-90}\right]
$$

The attributed share of foreign born and the attributed diversity index can be evaluated accordingly. In particular, the latter equals:

$$
\widehat{\operatorname{div}}_{c, 1990}=1-\sum_{i}\left(\widehat{C o B}_{i}^{c}\right)_{1990}^{2}
$$

As the attributed diversity for each city in 1990 is built using the city's shares in 1970 and the 1970-90 national growth rates of each group, this value is independent from any city-specific shock during the period.

Table 9 and 10 present the results of the IV estimation of the wage and rent regressions. Relative to previous regressions, some adjustments in the grouping of countries of birth is needed. This is because, as we input the shares in 1990 based on the initial shares in 1970, we need to identify the same countries of origin across census years. This is achieved by allocating more than one country of birth to the same group, as some countries have disappeared or changed during the period. In so doing, we follow the classification adopted by Card (2001) and described in the data appendix.

In Tables 9 and 10, Columns 1 report the OLS estimates of the basic specification. The point estimates of the OLS specification are very similar to the previous estimates (respectively Table 3, Columns 1 and 3) confirming that the reclassification by country groups has only negligible effects. The first stage regressions show that the imputed diversity indices are good predictors of the actual ones, explaining 20-30 percent of their variation (orthogonal to the other regressors) when all states are included. The exclusion of large immigration states, however, reduces significantly the partial $\mathrm{R}^{2}$ of the first stage regression.

The estimated effect of diversity on wages is reported in Column 2 of Table 9. Its value (0.95) is close 
to the OLS estimate and significantly positive. When we exclude the high-immigration states (column 3, Table 9), the effect of diversity is estimated to be positive but no longer significant. However, the main problem encountered when we exclude California, Florida and New York, is that, as just mentioned, the instruments lose much of their explanatory power (the partial $R^{2}$ of the excluded instruments drops to 0.120.17). Therefore, insignificance is mostly driven by large standard errors, rather than by evidence of any endogeneity bias (i.e., changes in point estimates).

In Table 10 the rent regression exhibits a similar qualitative pattern but sharper results. Using the shiftshare instruments, the diversity index has a positive and significant effect in each specification. Including all states, the IV estimates are almost double that of OLS (although, due to the large standard error we cannot reject the hypothesis that they are equal). When we exclude California, Florida, and New York (Specification 3 , Table 10), the standard errors increase significantly. However, the point estimates of the effect of diversity are still firmly in the positive range. Somewhat surprising (possibly driven by some outliers) is the very large (and imprecisely estimated) effect of diversity on rents in this specification.

All in all the results using shift-share instruments seem to confirm very strongly the positive effect of diversity on wages and rents of natives. In particular, considering all the IV regressions, we find no specification in which the coefficients of diversity are simultaneously not significant in both wage and rent

equations. Moreover the point estimates are always robustly positive (although sometimes not very precise due to instrument weakness). Thus, on the basis of the discussion in subsection 4.2 , we can conclude that our data support the hypothesis of a positive productivity effect of diversity with causation running from diversity to productivity of US workers.

\section{Discussion and Conclusions}

We looked at US metropolitan areas as a system of open cities in which cultural diversity may affect productivity and utility of natives. In principle, the effects of diversity can be positive or negative. We have considered a simple model that handles all possible cases (i.e. positive or negative effect on productivity and utility), and we have designed a simple identification procedure to figure out which case receives empirical support based on cross-city wage and rent variations.

We showed that higher wages and higher rents for US natives are significantly correlated with higher diversity. This result has survived several robustness checks against possible alternative explanations based on omitted variables and instrumental variables estimation.

Given our identification procedure, these findings are consistent only with a dominant positive effect of diversity on productivity: a more multicultural urban environment makes US-born citizens more productive. 
To the best of our knowledge, in terms of both data and identification procedure, our results are new.

As a concluding remark, it is worth pointing out that, while we have established the positive effect of foreign-born residents, we have not opened the 'black box' to analyze theoretically and empirically what are the channels through which that effect works. The complementarity of skills between US and foreign born seems a very promising avenue of research. Even at the same level of education, problem solving, creativity and adaptability may differ between native and foreign-born workers so that reciprocal learning may take place. Another promising avenue is that foreign-born workers may provide services that are not perfectly substitutable with those of natives. An Italian stylist, a Mexican cook or a Russian dancer, simply provide different services than their US-born counterparts. Because of a taste for variety, this may increase the value of total production. We need to analyze more closely the effects in different sectors and on different skill groups in order to gain better understanding of these channels. Overall our findings look plausible and encouraging, leaving to future research the important goal of pursuing further the analysis of the mechanisms through which foreign-born residents affect the US economy. 


\section{References}

[1] Alesina A. and E. La Ferrara (2003) Ethnic diversity and economic performance, NBER Working Paper No. 10313.

[2] Bairoch P. (1988) Cities and Economic Development: from the Dawn of History to the Present (Oxford: Oxford University Press).

[3] Berliant M. and M. Fujita (2004) Knowledge creation as a square dance on the Hilbert Cube, Washington University at Saint Louis, Department of Economics Working Paper.

[4] Boeri T., Hanson G. and B. McCormick (2002) Immigration Policy and the Welfare System (Oxford: Oxford University Press).

[5] Borjas G. (1994) The economics of immigration, Journal of Economic Literature, Vol. 32, 1667-1717.

[6] Borjas G. (1995) The economic benefits of immigration, Journal of Economic Perspectives, Vol. 9, 3-22.

[7] Borjas G. (1999) Heaven's Doors (Princeton: Princeton University Press).

[8] Borjas G. (2003) The labor demand curve is downward sloping: Re-examining the impact of immigration on the labor market, Quarterly Journal of Economics, Vol. 118, 1335-1374.

[9] Borjas G., R. Freeman and L. Katz (1997) How much do immigration and trade affect labor market outcomes?, Brookings Papers on Economic Activity, Vol. 1997, 1-90.

[10] Butcher K. and D. Card (1991) Immigration and wages, evidence from the 1980's, American Economic Review, Vol. 81, Papers and Proceedings of the Hundred and Third Annual Meeting of the American Economic Association, 292-296.

[11] Card D. (1990) The impact of the Mariel Boatlift on the Miami labor market, Industrial and Labor Relations Review, Vol. 43, 245-257.

[12] Card D. (2001) Immigrant inflows, native outflows and the local labor market impacts of higher immigration, Journal of Labor Economics, Vol. 19, 22-61.

[13] Card D. and J. Di Nardo (2000) Do immigrant inflows lead to native outflows?, American Economic Review, Vol. 90, 360-367.

[14] Card D. and A. Krueger (1992) School quality and black-white relative earnings: A direct assessment, Quarterly Journal of Economics, Vol. 107, 151-200. 
[15] Card D. and A. Krueger (1993) Trends in relative black-white earnings revisited, American Economic Review, Papers and Proceedings, Vol. 83, 85-91.

[16] Collier P. (2001) Implications of ethnic diversity, Economic Policy: a European Forum, Vol. 0, 127-55.

[17] Cutler D. and E. Glaeser (1997) Are ghettos good or bad?, Quarterly Journal of Economics, Vol.112, $827-72$.

[18] Easterly W. and R. Levine (1997) Africa's growth tragedy: Policies and ethnic division, Quarterly Journal of Economics, Vol.112, 1203-50.

[19] Eckstein Z. and K. Wolpin (1999) Estimating the effect of racial discrimination on first job wage offers, Review of Economics and Statistics, Vol. 81, 384-392.

[20] Florida R. (2002a) Bohemia and economic geography, Journal of Economic Geography, Vol. 2, 55-71.

[21] Florida R. (2002b) The Rise of the Creative Class (Basic Books, New York).

[22] Fujita, M., Krugman P. and A. Venables (1999) The Spatial Economy. Cities, regions and international trade (Cambridge MA: MIT Press).

[23] Glaeser E., Kolko J. and A. Saiz (2001) Consumer city, Journal of Economic Geography, Vol. 1, 27-50.

[24] Jacobs J. (1969) The Economy of Cities (New York: Random House).

[25] Lazear E. (1999) Globalization and the market for team-mates, Economic Journal,Vol. 109, C15-C40.

[26] Lian B. and J. Oneal (1997) Cultural diversity and economic development: A cross-national study of 98 Countries, 1960-1985, Economic Development and Cultural Change, Vol. 46, 61-77.

[27] Maignan, C., Ottaviano G., Pinelli D. and F. Rullani (2003) Bio-Ecological Diversity vs Socio-Economic Diversity: A Comparison of Existing Measures, FEEM, Working Paper n.13.2003.

[28] Mason P. (2000) Persistent discrimination: Racial disparity in the United States, 1967-1998, American Economic Review, Vol. 90, 312-16.

[29] Mauro P. (1995) Corruption and growth, Quarterly Journal of Economics, Vol. 110, 681-712.

[30] Moretti E. (2004) Workers' education, spillovers and productivity: Evidence from plant-level production functions, American Economic Review, Vol. 94, 656-690.

[31] Munshi, K. (2003) Networks in the modern economy: Mexican migrants in the US labor market, Quarterly Journal of Economics, Vol. 118, 549-599. 
[32] Ottaviano G. and G. Peri (2004a) Cities and cultures, CEPR Discussion Paper No. 4438.

[33] Ottaviano G. and G. Peri (2004b) The economic value of cultural diversity: Evidence from US Cities, CEPR Discussion Paper No. 4233 and CESifo Working Paper No. 1117.

[34] Park J. (1994) Estimation of sheepskin effects and returns to schooling using the old and new CPS Measures of educational attainment, Princeton University Industrial Relation Section, Working Paper No. 338.

[35] Quigley J. (1998) Urban diversity and economic growth, Journal of Economic Perspectives, Vol. 12, $127-138$.

[36] Rauch J. (1993) Productivity gains from geographic concentration in cities, Journal of Urban Economics, Vol. 34, 380-400.

[37] Roback J. (1982) Wages, rents and the quality of life, Journal of Political Economy, Vol. 90, 1257-78.

[38] Saiz A. (2003a) Room in the kitchen for the melting pot: Immigration and rental prices, Review of Economics and Statistics, Vol. 85, 3, 502-521.

[39] Saiz A. (2003b) Immigration and Housing Rents in American cities, Federal Reserve Bank of Philadelphia, Working Paper No. 03-12.

[40] Sassen S. (1994) Cities in a World Economy (Thousand Oaks: Pine Forge Press).

[41] Sivitanidou R. and W. Wheaton (1992) Wage and rent capitalization in the commercial real estate market, Journal of Urban Economics, Vol. 31, 206-229.

[42] Taylor C. and M. Hudson (1972) World Handbook of Political and Social Indicators, Second Edition (New Haven: Yale University Press).

[43] Winters, P., de Janvry A. and E. Sadoulet (2001) Family and community networks on Mexico-US migration, Journal of Human Resources, Vol. 36, 159-184. 


\section{A Data Appendix}

\section{A.1 Data for MSA's}

The data on cultural diversity and foreign-born are obtained from the 1970-1990 Public Use Microdata Sample (PUMS) of the US Census. We selected all people in working age (16-65) in each year and we identified the city where they lived using the SMSA code for 1990, while in 1970 we used the county group code to identify the metropolitan area. We used the variable 'Place of Birth' in order to identify the country of origin of the person. We considered only the countries of origin in which was born at least 0.5 percent of the foreign-born working age population. We obtained 35 groups for 1970 as well as for 1990.

We used the Variable 'Salary and Wage' to measure the yearly wage income of each person. We transformed the wage in real 1990 US $\$$ by deflating it with the national GDP deflator. The years of schooling for individuals are measured using the variable 'higrad' for the 1970 census, which indicates the highest grade attended, while for 1990 the variable 'grade completed' is converted into years of schooling using Park's (1994) correspondence Table 4. Average rents are calculated using gross monthly rent per room (i.e. Rent divided by number of rooms) expressed in real 1990 US $\$$ terms. The data on total city employment, total local public spending, and public spending in education are from the County and City Databook.

The list of metropolitan areas used in our study is reported in the following table. 


\begin{tabular}{|c|c|c|c|}
\hline \multicolumn{4}{|c|}{ Name and state of the cities used } \\
\hline Abilene, TX & Dayton-Springfield, $\mathrm{OH}$ & Lexington, $\mathrm{KY}$ & Rockford, IL \\
\hline Akron, $\mathrm{OH}$ & Decatur, IL & Lima, $\mathrm{OH}$ & Sacramento, CA \\
\hline $\begin{array}{l}\text { Albany-Schenectady-Troy, } \\
\text { NY }\end{array}$ & Denver, CO & Lincoln, NE & Saginaw-Bay City-Midland, MI \\
\hline Albuquerque, NM & Des Moines, IA & $\begin{array}{l}\text { Little Rock-North Little Rock, } \\
\text { AR }\end{array}$ & St. Louis, MO-IL \\
\hline $\begin{array}{l}\text { Allentown-Bethlehem- } \\
\text { Easton, PA }\end{array}$ & Detroit, MI & Los Angeles-Long Beach, CA & Salem, OR \\
\hline Altoona, PA & Duluth-Superior, MN-WI & Louisville, KY-IN & Salinas, CA \\
\hline Amarillo, TX & El Paso, TX & Lubbock, TX & Salt Lake City-Ogden, UT \\
\hline $\begin{array}{l}\text { Appleton-Oshkosh-Neenah, } \\
\text { WI }\end{array}$ & Erie, PA & Macon, GA & San Antonio, TX \\
\hline Atlanta, GA & Eugene-Springfield, OR & Madison, WI & San Diego, CA \\
\hline Atlantic-Cape May, NJ & Fayetteville, NC & Mansfield, $\mathrm{OH}$ & San Francisco, CA \\
\hline Augusta-Aiken, GA-SC & Flint, Ml & Memphis, TN-AR-MS & San Jose, CA \\
\hline Austin-San Marcos, TX & Fort Lauderdale, FL & Miami, FL & $\begin{array}{l}\text { Santa Barbara-Santa Maria- } \\
\text { Lompoc, CA }\end{array}$ \\
\hline Bakersfield, CA & Fort Wayne, IN & Milwaukee-Waukesha, WI & Santa Rosa, CA \\
\hline Baltimore, MD & Fresno, CA & Minneapolis-St. Paul, MN-WI & Seattle-Bellevue-Everett, WA \\
\hline Baton Rouge, LA & Gainesville, FL & Modesto, CA & Shreveport-Bossier City, LA \\
\hline Beaumont-Port Arthur, TX & Gary, IN & Monroe, LA & South Bend, IN \\
\hline Billings, MT & $\begin{array}{l}\text { Grand Rapids-Muskegon- } \\
\text { Holland, MI }\end{array}$ & Montgomery, AL & Spokane, WA \\
\hline $\begin{array}{l}\text { Biloxi-Gulfport-Pascagoula, } \\
\text { MS }\end{array}$ & Green Bay, WI & Muncie, IN & Springfield, MO \\
\hline Binghamton, NY & $\begin{array}{l}\text { Greensboro--Winston-Salem- } \\
\text {-High Point, NC }\end{array}$ & Nashville, TN & Stockton-Lodi, CA \\
\hline Birmingham, AL & $\begin{array}{l}\text { Greenville-Spartanburg- } \\
\text { Anderson, SC }\end{array}$ & New Orleans, LA & Syracuse, NY \\
\hline Bloomington-Normal, IL & Hamilton-Middletown, $\mathrm{OH}$ & New York, NY & Tacoma, WA \\
\hline Boise City, ID & $\begin{array}{l}\text { Harrisburg-Lebanon-Carlisle, } \\
\text { PA }\end{array}$ & Newark, NJ & $\begin{array}{l}\text { Tampa-St. Petersburg- } \\
\text { Clearwater, FL }\end{array}$ \\
\hline $\begin{array}{l}\text { Brownsville-Harlingen-San } \\
\text { Benito, TX }\end{array}$ & Honolulu, $\mathrm{HI}$ & $\begin{array}{l}\text { Norfolk-Virginia Beach- } \\
\text { Newport News, VA-NC }\end{array}$ & Terre Haute, IN \\
\hline Buffalo-Niagara Falls, NY & Houston, TX & Odessa-Midland, TX & Toledo, $\mathrm{OH}$ \\
\hline Canton-Massillon, $\mathrm{OH}$ & $\begin{array}{l}\text { Huntington-Ashland, WV-KY- } \\
\mathrm{OH}\end{array}$ & Oklahoma City, OK & Trenton, NJ \\
\hline Cedar Rapids, IA & Indianapolis, IN & Omaha, NE-IA & Tucson, AZ \\
\hline Champaign-Urbana, IL & Jackson, Ml & Orlando, FL & Tulsa, OK \\
\hline $\begin{array}{l}\text { Charleston-North } \\
\text { Charleston, SC }\end{array}$ & Jackson, MS & Pensacola, FL & Tuscaloosa, AL \\
\hline $\begin{array}{l}\text { Charlotte-Gastonia-Rock } \\
\text { Hill, NC-SC }\end{array}$ & Jacksonville, FL & Peoria-Pekin, IL & Tyler, TX \\
\hline Chattanooga, TN-GA & Jersey City, NJ & Philadelphia, PA-NJ & Utica-Rome, NY \\
\hline Chicago, IL & Johnstown, PA & Phoenix-Mesa, AZ & Vallejo-Fairfield-Napa, CA \\
\hline Cincinnati, OH-KY-IN & Kalamazoo-Battle Creek, MI & Pittsburgh, PA & Waco, TX \\
\hline Cleveland-Lorain-Elyria, $\mathrm{OH}$ & Kansas City, MO-KS & Portland-Vancouver, OR-WA & Washington, DC-MD-VA-WV \\
\hline Colorado Springs, CO & Kenosha, WI & $\begin{array}{l}\text { Raleigh-Durham-Chapel Hill, } \\
\text { NC }\end{array}$ & Waterloo-Cedar Falls, IA \\
\hline Columbia, MO & Knoxville, TN & Reading, PA & $\begin{array}{l}\text { West Palm Beach-Boca Raton, } \\
\text { FL }\end{array}$ \\
\hline Columbia, SC & Lafayette, LA & Reno, NV & Wichita, KS \\
\hline Columbus, $\mathrm{OH}$ & Lafayette, IN & Richmond-Petersburg, VA & Wilmington-Newark, DE-MD \\
\hline Corpus Christi, TX & Lancaster, PA & $\begin{array}{l}\text { Riverside-San Bernardino, } \\
\text { CA }\end{array}$ & Wilmington, NC \\
\hline Dallas, TX & Lansing-East Lansing, MI & Roanoke, VA & York, PA \\
\hline $\begin{array}{l}\text { Davenport-Moline-Rock } \\
\text { Island, IA-IL }\end{array}$ & Las Vegas, NV-AZ & Rochester, NY & Youngstown-Warren, $\mathrm{OH}$ \\
\hline
\end{tabular}

\section{A.2 Grouping by Country of Birth}

In Tables from 1 to 8 we consider the diversity index constructed using 35 countries of origin of immigrants which top the list of all countries of origin plus a residual group called 'others'. These account for more than 90 percent of all foreign-born, both in 1970 and 1990, and a country that is not in this list supplies at most 
0.5 percent of all foreign-born living in the US. Here is the list of the non-residual countries, in alphabetical order. For year 1970 the countries are: Argentina, Australia, Canada, Czechoslovakia, China, Colombia, Cuba, Dominican Republic, England, France, Germany, Greece, Hungary, India, Ireland, Italy, Jamaica, Japan, Korea, Latvia, Lithuania, Mexico, Netherlands, Norway, Philippines, Poland, Portugal, Romania, Scotland, Sweden, Syria, Ukraine, USSR, Yugoslavia, Others. For 1990 the countries are: Argentina, Canada, China, Colombia, Cuba, Dominican Republic, Ecuador, England, France, Germany, Greece, Guyana, Haiti, Honduras, Hong-Kong, India, Iran, Ireland, Italy, Jamaica, Japan, Korea, Mexico, Nicaragua, Panama, Peru, Philippines, Poland, Portugal, El Salvador, Taiwan, Trinidad and Tobago, USSR, Vietnam, Yugoslavia.

In Tables 9 and 10, in order to have the same groups in 1970 and 1990, we allocate more than one non-residual country to the same group based on geographical proximity. Our fifteen groups are almost the same as those defined and used in Card (2001). This is the list: Mexico, Caribbean Countries, Central America, China-Hong-Kong-Singapore, South America, South East Asia, Korea and Japan, Philippines, Australia-New Zealand-Canada-UK, India and Pakistan, Russia and Central Europe, Turkey, North Africa and Middle East, Northwestern Europe and Israel, South-western Europe, Sub-Saharan Africa, Cuba. 


\section{Tables and Figures}

Table 1

Foreign Born living in 160 U.S. metropolitan areas

15 Largest Groups 1970, 1990

\begin{tabular}{|l|r|l|r|}
\hline Country of Origin & $\begin{array}{l}\text { Percentage of total } \\
\text { Foreign Born 1970 }\end{array}$ & Country of Origin & $\begin{array}{r}\text { Percentage of total } \\
\text { Foreign Born 1990 }\end{array}$ \\
\hline Canada & $9.0 \%$ & Mexico & $20.0 \%$ \\
\hline Italy & $8.1 \%$ & Philippines & $6.0 \%$ \\
\hline Germany & $7.8 \%$ & Cuba & $4.2 \%$ \\
\hline Mexico & $7.3 \%$ & Germany & $3.2 \%$ \\
\hline Syria & $7.0 \%$ & Canada & $3.2 \%$ \\
\hline Cuba & $5.1 \%$ & China & $2.8 \%$ \\
\hline Poland & $4.5 \%$ & India & $2.8 \%$ \\
\hline UK & $4.4 \%$ & Viet-Nam & $2.7 \%$ \\
\hline Philippine & $2.3 \%$ & El Salvador & $2.6 \%$ \\
\hline USSR & $2.3 \%$ & Italy & $2.4 \%$ \\
\hline Ireland & $2.3 \%$ & Korea & $2.2 \%$ \\
\hline China & $2.3 \%$ & UK & $2.2 \%$ \\
\hline Yugoslavia & $1.7 \%$ & Japan & $1.8 \%$ \\
\hline Greece & $1.6 \%$ & Jamaica & $1.7 \%$ \\
\hline Hungary & $1.6 \%$ & Colombia & $1.6 \%$ \\
\hline $\begin{array}{l}\text { Foreign Born as \% } \\
\text { of working age total } \\
\text { population , 1970 }\end{array}$ & $8.0 \%$ & $\begin{array}{l}\text { Foreign Born as } \\
\text { \% of working age } \\
\text { total population },\end{array}$ \\
\hline
\end{tabular}

Source: Authors' Elaborations on 1970 and 1990 PUMS Census Data. 
Table 2

Diversity in representative Metropolitan Areas, 1990

\begin{tabular}{|c|c|c|c|}
\hline city & $\begin{array}{l}\text { Share of } \\
\text { Foreign Born }\end{array}$ & $\begin{array}{l}\text { Country of Origin of the } \\
\text { Five Largest foreign } \\
\text { Groups }\end{array}$ & $\begin{array}{l}\text { Diversity } \\
\text { Index }\end{array}$ \\
\hline Atlanta, GA & $5.8 \%$ & $\begin{array}{l}\text { Germany, Mexico, India, } \\
\text { England, Korea }\end{array}$ & 0.11 \\
\hline Chicago, IL & $15.2 \%$ & $\begin{array}{l}\text { Mexico, Poland, } \\
\text { Philippines, India, } \\
\text { Germany }\end{array}$ & 0.28 \\
\hline Cincinnati, OH-KY-IN & $2.3 \%$ & $\begin{array}{l}\text { Germany, England, India, } \\
\text { Canada, Viet-Nam }\end{array}$ & 0.057 \\
\hline Dallas, TX & $10.6 \%$ & $\begin{array}{l}\text { Mexico, Salvador, Viet- } \\
\text { Nam, India, Germany }\end{array}$ & 0.20 \\
\hline El Paso, TX & $29 \%$ & $\begin{array}{l}\text { Mexico, Japan, Korea, } \\
\text { Canada, Panama }\end{array}$ & 0.43 \\
\hline Indianapolis, IN & $2.3 \%$ & $\begin{array}{l}\text { Germany, England, Korea, } \\
\text { Canada, Philippines }\end{array}$ & 0.046 \\
\hline Las Vegas, NE & $12 \%$ & $\begin{array}{l}\text { Mexico, Philippines, } \\
\text { Germany, Canada, Cuba }\end{array}$ & 0.23 \\
\hline Los Angeles, CA & $37 \%$ & $\begin{array}{l}\text { Mexico, Salvador, } \\
\text { Philippines, Guatemala, } \\
\text { Korea }\end{array}$ & 0.58 \\
\hline New York, NY & $31 \%$ & $\begin{array}{l}\text { Dominican Republic, } \\
\text { China, Jamaica, Italy, } \\
\text { Colombia }\end{array}$ & 0.51 \\
\hline Oklahoma City, OK & $4.1 \%$ & $\begin{array}{l}\text { Mexico, Viet-Nam, } \\
\text { Germany, England, Japan }\end{array}$ & 0.08 \\
\hline Philadelphia, PA-NJ & $5 \%$ & $\begin{array}{l}\text { Germany, India, Italy, } \\
\text { England, Philippines }\end{array}$ & 0.10 \\
\hline Pittsburgh, PA & $2.3 \%$ & $\begin{array}{l}\text { Italy, Germany, India, } \\
\text { England, Canada }\end{array}$ & 0.04 \\
\hline Sacramento, CA & $10.6 \%$ & $\begin{array}{l}\text { Mexico, Philippines, } \\
\text { Germany, China, Canada }\end{array}$ & 0.19 \\
\hline San Francisco, CA & $30.3 \%$ & $\begin{array}{l}\text { Philippines, China, Mexico, } \\
\text { Salvador, Hong Kong }\end{array}$ & $\mathbf{0 . 5 0}$ \\
\hline Washington, DC-MD-VA-WV & $14.8 \%$ & $\begin{array}{l}\text { Salvador, Germany, India, } \\
\text { Korea, Viet-Nam }\end{array}$ & 0.27 \\
\hline
\end{tabular}

Source: Authors' Elaborations on 1970 and 1990 PUMS Census Data. 
Table 3

Basic Wage and Rent Regressions

\begin{tabular}{|c|c|c|c|c|}
\hline Specification & \multicolumn{2}{|c|}{ Wage Equation } & \multicolumn{2}{|c|}{ Rent Equation } \\
\hline $\begin{array}{l}\text { Dependent } \\
\text { Variable }\end{array}$ & $\begin{array}{l}\text { I } \\
\text { In(Wage) }\end{array}$ & $\begin{array}{l}\text { II } \\
\text { In(Wage) }\end{array}$ & $\begin{array}{l}\text { III } \\
\ln (\text { Rent })\end{array}$ & $\begin{array}{l}\text { IV } \\
\ln (\text { Rent })\end{array}$ \\
\hline $\begin{array}{l}\text { Average } \\
\text { Schooling }\end{array}$ & $\begin{array}{l}0.10 * * \\
(0.01)\end{array}$ & $\begin{array}{l}0.10 * * \\
(0.01)\end{array}$ & & \\
\hline $\begin{array}{l}\text { ln(Income per } \\
\text { capita) }\end{array}$ & & & $\begin{array}{l}0.67 * * \\
(0.08)\end{array}$ & $\begin{array}{l}0.66^{* *} \\
(0.08)\end{array}$ \\
\hline $\ln ($ Employment $)$ & $\begin{array}{l}0.02 \\
(0.02) \\
\end{array}$ & $\begin{array}{l}0.01 \\
(0.02)\end{array}$ & & \\
\hline $\ln$ (population) & & & $\begin{array}{l}0.03 \\
(0.04)\end{array}$ & $\begin{array}{l}0.06 \\
(0.04)\end{array}$ \\
\hline Diversity Index & $\begin{array}{l}1.29 * * \\
(0.29) \\
\end{array}$ & & $\begin{array}{l}0.95^{* *} \\
(0.50) \\
\end{array}$ & \\
\hline $\begin{array}{l}\text { Share of Foreign } \\
\text { Born }\end{array}$ & & $\begin{array}{l}0.58^{* *} \\
(0.11)\end{array}$ & & $\begin{array}{l}0.53^{* *} \\
(0.20)\end{array}$ \\
\hline $\begin{array}{l}\text { Diversity Index } \\
\text { Among Foreign } \\
\text { Born }\end{array}$ & & $\begin{array}{l}0.14^{*} \\
(0.08)\end{array}$ & & $\begin{array}{l}0.16 \\
(0.13)\end{array}$ \\
\hline $\begin{array}{l}\text { City Fixed } \\
\text { Effects }\end{array}$ & Yes & Yes & Yes & Yes \\
\hline $\begin{array}{l}\text { Time Fixed } \\
\text { Effects }\end{array}$ & Yes & Yes & Yes & Yes \\
\hline $\begin{array}{l}\mathrm{R}^{2} \\
\text { (excluding city } \\
\text { and time fixed } \\
\text { effects) }\end{array}$ & 0.10 & 0.12 & 0.30 & 0.31 \\
\hline Observations & 320 & 320 & 320 & 320 \\
\hline
\end{tabular}

Specification I and II: Dependent Variable is logged average yearly wage of white, USBorn, males 40-50 years in 1990 U.S. \$.

Specification III and IV: Dependent Variable is logged average monthly rent per room paid by white, U.S. Born, expressed in 1990 U.S. $\$$.

** significant at $5 \%$, * significant at $10 \%$

In Parenthesis: Heteroskedasticity-Robust Standard Errors. 
Table 4

Correlation between Growth in Diversity and in Employment/Population

\begin{tabular}{|l|l|l|l|l|l|}
\hline $\begin{array}{l}\text { Dependent } \\
\text { variable: }\end{array}$ & $\begin{array}{l}\text { Index of } \\
\text { Diversity }\end{array}$ & $\begin{array}{l}\text { City } \\
\text { Fixed } \\
\text { Effects }\end{array}$ & $\begin{array}{l}\text { Time fixed } \\
\text { effects }\end{array}$ & $\mathbf{R}^{\mathbf{2}}$ & Observations \\
\hline Ln(Employment) & $\begin{array}{l}0.72 \\
(1.12)\end{array}$ & Yes & Yes & 0.97 & 320 \\
\hline Ln(Population) & $\begin{array}{l}1.70^{*} \\
(1.02)\end{array}$ & Yes & Yes & 0.97 & 320 \\
\hline
\end{tabular}

** significant at $5 \%$, * significant at $10 \%$

Heteroskedasticity-Robust Standard Errors are reported in Parentheses. 
Table 5

Wage Regression: Robustness Checks

\begin{tabular}{|l|l|l|l|}
\hline Specification & $\begin{array}{l}\text { 1 } \\
\text { Coefficient on } \\
\text { the Diversity } \\
\text { Index }\end{array}$ & $\begin{array}{l}\text { 2 } \\
\text { Coefficient on } \\
\text { the Share of } \\
\text { Foreign Born }\end{array}$ & $\begin{array}{l}\text { 3 } \\
\text { Coefficient on } \\
\text { Diversity Index } \\
\text { Among Foreign } \\
\text { Born }\end{array}$ \\
\hline Specification: & \multicolumn{2}{l|}{} \\
\hline (1) Basic & $1.29^{* *}$ & $0.58^{* *}$ & $0.14^{*}$ \\
& $(0.29)$ & $(0.11)$ & $(0.08)$ \\
\hline (2) Including schooling of Foreign & $1.25^{* *}$ & $0.58^{* *}$ & $0.14^{*}$ \\
Born & $(0.38)$ & $(0.16)$ & $(0.09)$ \\
\hline (3) Including share of Out of State & $1.34^{* *}$ & $0.61^{* *}$ & 0.09 \\
Born & $(0.38)$ & $(0.16)$ & $(0.09)$ \\
\hline (4) Including share of non Whites & $1.38^{* *}$ & $0.68^{* *}$ & 0.13 \\
& $(0.40)$ & $(0.18)$ & $(0.10)$ \\
\hline (5) Including Public Spending on & $1.28^{* *}$ & $0.62^{* *}$ & $0.16^{* *}$ \\
local Services per capita & $(0.38)$ & $(0.17)$ & $(0.08)$ \\
\hline (6) Including Public Spending in & $1.24^{* *}$ & $0.61^{* *}$ & $0.15^{*}$ \\
Education per capita & $(0.38)$ & $(0.16)$ & $(0.08)$ \\
\hline (7) Including Employment of & $1.30^{* *}$ & $0.70^{*}$ & 0.15 \\
white-US born males 40-50. & $(0.42)$ & $(0.18)$ & $(0.10)$ \\
\hline (8) Including All of the Above & $1.40^{* *}$ & $0.74^{* *}$ & 0.09 \\
& $(0.40)$ & $(0.18)$ & $(0.08)$ \\
\hline (9) Basic without CA, FL, NY & $0.97^{* *}$ & 0.30 & $0.21^{* *}$ \\
& $(0.50)$ & $(0.27)$ & $(0.10)$ \\
\hline (10) in Changes 1990-1970 with & $1.05^{* *}$ & $0.64^{* *}$ & 0.03 \\
State-Fixed Effects & $(0.33)$ & $(0.18)$ & $(0.10)$ \\
\hline (11) Using wage of white-US born & $1.14^{*}$ & $0.60^{*}$ & 0.05 \\
males 30-40 as dep. variable & $(0.36)$ & $(0.15)$ & $(0.10)$ \\
\hline
\end{tabular}

Dependent Variable: In average yearly wage to white, U.S. Born, males 40-50 years old expressed in 1990 U.S. \$.

(1) Basic: Specification from Table 3 Column I (for coefficient 1) and Column II (for coefficients 2 and 3)

(2) Includes average years of schooling of foreign born

(3) Includes the share of U.S. born outside the state in which they live

(4) Includes the share of non-white people in working age

(5) Include the Spending per capita on local government services.

(6) Includes the Spending in Education per Capita

(7) Includes $\ln$ (Employment) of the group US-Born, white males 40-50 years old

(8) Includes all the variables in (1)-(7) together as controls

(9) Excluding from the regression MSAs in the biggest immigrations states: CA, FL, NY

(10) Regression in Changes including 49 State Fixed-Effects

(11) Uses the wage of the group white, U.S. Born, males, 30-40 years old as dependent variable

** significant at $5 \%$, * significant at $10 \%$

Heteroskedasticity-Robust Standard Errors are reported in Parentheses. 
Table 6

Rent Regression: Robustness Checks

\begin{tabular}{|l|l|l|l|}
\hline Specification & $\begin{array}{l}\mathbf{1} \\
\text { Coefficient on } \\
\text { the Diversity } \\
\text { Index }\end{array}$ & $\begin{array}{l}\mathbf{2} \\
\text { Coefficient on } \\
\text { the Share of } \\
\text { Foreign Born }\end{array}$ & $\begin{array}{l}\text { 3 } \\
\text { Coefficient on } \\
\text { Diversity Index } \\
\text { Among Foreign } \\
\text { Born }\end{array}$ \\
\hline Specification: & \multicolumn{2}{|l|}{} \\
\hline (1) Basic & $0.95^{* *}$ & $0.53^{* *}$ & 0.11 \\
& $(0.50)$ & $(0.20)$ & $0.16)$ \\
\hline (2) Including schooling of Foreign & $0.92^{*}$ & $0.58^{* *}$ & 0.17 \\
Born & $(0.49)$ & $(0.22)$ & $(0.14)$ \\
\hline (3) Including share of Out of State & $0.86^{*}$ & $0.52^{* *}$ & 0.16 \\
Born & $(0.50)$ & $(0.24)$ & $(0.15)$ \\
\hline (4) Including share of non Whites & 0.71 & $0.44^{* *}$ & 0.14 \\
& $(0.50)$ & $(0.25)$ & $(0.13)$ \\
\hline (5) Including Public Spending on & $0.89^{*}$ & $0.53^{* *}$ & 0.18 \\
local Services per capita & $(0.50)$ & $(0.24)$ & $(0.14)$ \\
\hline (6) Including Public Spending in & $0.94^{* *}$ & $0.53^{* *}$ & 0.14 \\
Education per capita & $(0.50)$ & $(0.24)$ & $(0.14)$ \\
\hline (7) Including population of white & 0.69 & $0.50^{*}$ & 0.16 \\
US-born males & $(0.50)$ & $(0.28)$ & $(0.13)$ \\
\hline (8) Including All of the Above & 0.72 & $0.53^{* *}$ & 0.15 \\
& $(0.50)$ & $(0.24)$ & $(0.14)$ \\
\hline (9) Basic without CA, FL, NY & $2.99^{* *}$ & $0.74^{*}$ & 0.10 \\
& $(1.19)$ & $(0.39)$ & $(0.10)$ \\
\hline (10) in Changes 1990-1970 with & 0.13 & 0.03 & 0.15 \\
State-Fixed Effects & $(0.42)$ & $(0.23)$ & $(0.17)$ \\
\hline
\end{tabular}

Dependent Variable: In average monthly Rent paid by white, U.S. Born, expressed in 1990 U.S. \$.

(1) Basic: Specification from Table 4 Column II (for coefficient 1) and Column IV (for coefficients 2 and 3 )

(2) Includes average years of schooling of foreign born

(3) Includes the share of U.S. born outside the state in which they live

(4) Includes the share of non-white people in working age

(5) Include the Spending per capita on local government services.

(6) Includes the Spending in Education per Capita

(7) Includes the $\ln$ (population) of white US-born males.

(8) Includes all the variables in (1)-(7) together as controls

(9) Excluding from the regression MSAs in the biggest immigrations states (CA, FL, NY)

(10) Regression in Changes including 49 State Fixed-Effects

** significant at 5\%, * significant at $10 \%$

Heteroskedasticity-Robust Standard Errors are reported in Parentheses. 
Table 7

Wage Regression

IV Estimation, Instrument: Distance from "Gateways" into the US.

\begin{tabular}{|c|c|c|c|}
\hline Dependent Variable $: \Delta \ln ($ Wage $)$ & $\begin{array}{l}1 \\
\text { IV }\end{array}$ & $\begin{array}{l}2 \\
\text { IV with } \\
\text { State Effects }\end{array}$ & $\begin{array}{l} \\
\text { Non-Coastal Cities }\end{array}$ \\
\hline$\Delta$ Schooling & $\begin{array}{l}0.11 * * \\
(0.01)\end{array}$ & $\begin{array}{l}0.10^{* *} \\
(0.02)\end{array}$ & $\begin{array}{l}0.11^{* *} \\
(0.02)\end{array}$ \\
\hline$\Delta \ln (\mathbf{E m p l})$ & $\begin{array}{l}0.02 \\
(0.02) \\
\end{array}$ & $\begin{array}{l}0.07 \\
(0.04) \\
\end{array}$ & $\begin{array}{l}0.04 \\
(0.04)\end{array}$ \\
\hline$\Delta$ (Diversity) & $\begin{array}{l}1.55^{* *} \\
(0.47)\end{array}$ & $\begin{array}{l}1.23 * * \\
(0.42)\end{array}$ & $\begin{array}{l}4.70^{*} \\
(2.40)\end{array}$ \\
\hline State Fixed Effects & No & Yes & No \\
\hline $\mathbf{R}^{2}$ & 0.35 & 0.65 & 0.30 \\
\hline Observations & 160 & 160 & 144 \\
\hline \multicolumn{4}{|c|}{ First Stage Regression } \\
\hline Ln(Distance from LA) & $\begin{array}{l}-0.038^{* *} \\
(0.004)\end{array}$ & $\begin{array}{l}-0.038^{* *} \\
(0.004)\end{array}$ & $\begin{array}{l}-0.034 * * \\
(0.006)\end{array}$ \\
\hline Ln(Distance from NY) & $\begin{array}{l}-0.004 * * \\
(0.002) \\
\end{array}$ & $\begin{array}{l}-0.004 * * \\
(0.002) \\
\end{array}$ & $\begin{array}{l}-0.003 \\
(0.003) \\
\end{array}$ \\
\hline Ln(Distance from Miami) & $\begin{array}{l}-0.023^{* *} \\
(0.003)\end{array}$ & $\begin{array}{l}-0.023^{* *} \\
(0.003)\end{array}$ & $\begin{array}{l}-0.023^{* *} \\
(0.007)\end{array}$ \\
\hline Ln(Distance from Border) & $\begin{array}{l}-0.002 * * \\
(0.001) \\
\end{array}$ & $\begin{array}{l}-0.002 * * \\
(0.001)\end{array}$ & $\begin{array}{l}-0.004 * * \\
(0.002)\end{array}$ \\
\hline Partial $\mathbf{R}^{2}$ & 0.52 & 0.28 & 0.25 \\
\hline
\end{tabular}

Dependent Variable: Change between 1970 and 1990 in ln average yearly wage of white, U.S. Born, males, 40-50 years, expressed in 1990 U.S. \$. ** significant at 5\%, * significant at $10 \%$

Heteroskedasticity-Robust Standard Errors are reported in Parentheses. 


\section{Table 8}

\section{Rent Regression}

IV Estimation, Instrument: Distance from "Gateways" into the US.

\begin{tabular}{|l|l|l|l|}
\hline Dependent Variable : $\Delta \ln ($ Rent) & $\mathbf{1}$ & $\begin{array}{l}\mathbf{2} \\
\text { IV with State } \\
\text { Effects }\end{array}$ & $\begin{array}{l}\mathbf{3} \\
\text { Non-Coastal } \\
\text { Cities }\end{array}$ \\
\hline$\Delta \ln ($ Income) & $0.65^{* *}$ & $0.47^{* *}$ \\
$(0.12)$ & $0.39^{*}$ \\
& $(0.10)$ & $0.17)$ \\
\hline$\Delta \ln ($ Pop) & 0.03 & 0.04 & 0.02 \\
& $(0.04)$ & $(0.08)$ & $(0.14)$ \\
\hline$\Delta$ (Diversity) & 1.60 & 0.17 & $5.90^{* *}$ \\
& $(1.00)$ & $(0.48)$ & $(1.80)$ \\
\hline State Fixed Effects & No & Yes & No \\
\hline $\mathbf{R}^{2}$ & 0.35 & 0.73 & 0.14 \\
\hline Observations & 160 & 160 & 144 \\
\hline & First Stage Regression & $-0.034^{* *}$ \\
\hline Ln(Distance from LA) & $-0.038^{* *}$ & $-0.038^{* *}$ & $(0.006)$ \\
\hline Ln(Distance from NY) & $(0.004)$ & $(0.004)$ & -0.003 \\
& $-0.004^{* *}$ & $-0.004^{* *}$ & $(0.003)$ \\
\hline Ln(Distance from Miami) & $(0.002)$ & $(0.002)$ & $-0.023^{* *}$ \\
& $-0.023^{* *}$ & $-0.023^{* *}$ & $(0.007)$ \\
\hline Ln(Distance from Border) & $(0.003)$ & $(0.003)$ & $-0.004^{* *}$ \\
& $-0.002^{* *}$ & $-0.002^{* *}$ & $(0.002)$ \\
\hline Partial R ${ }^{2}$ & $(0.001)$ & $(0.001)$ & 0.20 \\
\hline
\end{tabular}

Dependent Variable: Change between 1970 and 1990 in ln average monthly rent paid by white, U.S. Born, expressed in 1990 U.S. \$.

$* *$ significant at $5 \%, *$ significant at $10 \%$

Heteroskedasticity-Robust Standard Errors are reported in Parentheses. 
Table 9

Wage Regression

IV Estimation, Instrument: Shift-Share Constructed Diversity.

\begin{tabular}{|c|c|c|c|}
\hline Dependent Variable $: \Delta \ln ($ Wage $)$ & $\begin{array}{l}1 \\
\text { OLS }\end{array}$ & $\begin{array}{l}2 \\
\text { IV }\end{array}$ & $\begin{array}{l}3 \\
\text { IV Without } \\
\text { CA-FL-NY }\end{array}$ \\
\hline$\Delta$ Schooling & $\begin{array}{l}0.11 * * \\
(0.01)\end{array}$ & $\begin{array}{l}0.11^{* *} \\
(0.01)\end{array}$ & $\begin{array}{l}0.10^{* * *} \\
(0.02)\end{array}$ \\
\hline$\Delta \ln ($ Empl $)$ & $\begin{array}{l}0.02 \\
(0.02)\end{array}$ & $\begin{array}{l}0.04 \\
(0.03)\end{array}$ & $\begin{array}{l}0.03 \\
(0.03)\end{array}$ \\
\hline$\Delta$ (Diversity) & $\begin{array}{l}1.27 * * \\
(0.27)\end{array}$ & $\begin{array}{l}0.95^{* *} \\
(0.50)\end{array}$ & $\begin{array}{l}0.92 \\
(0.65)\end{array}$ \\
\hline $\mathbf{R}^{2}$ & 0.36 & 0.35 & 0.34 \\
\hline Observations & 160 & 160 & 145 \\
\hline \multicolumn{4}{|c|}{ Fist Stage Regression } \\
\hline Shift-Share Constructed Diversity & n.a. & $\begin{array}{l}0.51 * * \\
(0.05)\end{array}$ & $\begin{array}{l}0.21 * * \\
(0.04)\end{array}$ \\
\hline Partial $\mathbf{R}^{2}$ & n.a. & 0.31 & 0.17 \\
\hline
\end{tabular}

Dependent Variable: Change between 1970 and 1990 in ln average yearly wage of white, U.S. Born, males, 40-50 years, expressed in 1990 U.S. \$.

Instrumental Variable: Imputed change in diversity index and share of foreign born, using the shift-share method.

** significant at $5 \%$, * significant at $10 \%$

Heteroskedasticity-Robust Standard Errors are reported in Parentheses. 
Table 10

Rent Regression

IV Estimation, Instrument: Shift-Share constructed Diversity.

\begin{tabular}{|c|c|c|c|}
\hline $\begin{array}{l}\text { Dependent Variable : } \\
\Delta \ln (\text { Rent })\end{array}$ & 1 & $\begin{array}{l}2 \\
\text { IV }\end{array}$ & $\begin{array}{l}3 \\
\text { IV, Without } \\
\text { CA-FL-NY }\end{array}$ \\
\hline$\Delta \ln ($ Population $)$ & $\begin{array}{l}0.03 \\
(0.04)\end{array}$ & $\begin{array}{l}0.04 \\
(0.04)\end{array}$ & $\begin{array}{l}0.04 \\
(0.06) \\
\end{array}$ \\
\hline$\Delta \ln ($ Income $)$ & $\begin{array}{l}0.67^{*} \\
(0.09)\end{array}$ & $\begin{array}{l}0.61^{*} \\
(0.10)\end{array}$ & $\begin{array}{l}0.48^{* *} \\
(0.09)\end{array}$ \\
\hline$\Delta$ (Diversity) & $\begin{array}{l}1.10^{*} \\
(0.70)\end{array}$ & $\begin{array}{l}2.60^{* * *} \\
(1.02)\end{array}$ & $\begin{array}{l}4.21 * * \\
(1.60)\end{array}$ \\
\hline $\mathbf{R}^{2}$ & 0.38 & 0.33 & 0.28 \\
\hline Observations & 160 & 160 & 145 \\
\hline \multicolumn{4}{|c|}{ First Stage Regression } \\
\hline $\begin{array}{l}\text { Shift-Share Constructed } \\
\text { Diversity }\end{array}$ & n.a. & $\begin{array}{l}0.51 * * \\
(0.05)\end{array}$ & $\begin{array}{l}0.21 * * \\
(0.04)\end{array}$ \\
\hline Partial $\mathbf{R}^{2}$ & n.a. & 0.23 & 0.11 \\
\hline
\end{tabular}

Dependent Variable: Change between 1970 and 1990 in logged average yearly rent of white, U.S. Born, expressed in 1990 U.S. \$.

Instrumental Variable: Imputed change in diversity index and share of foreign born, using the shift-share method, described in the main text.

** significant at $5 \%$, * significant at $10 \%$

Heteroskedasticity-Robust Standard Errors are reported in Parentheses. 
Figure 1 - Wages of US-born and Diversity

160 U.S. Metropolitan Areas

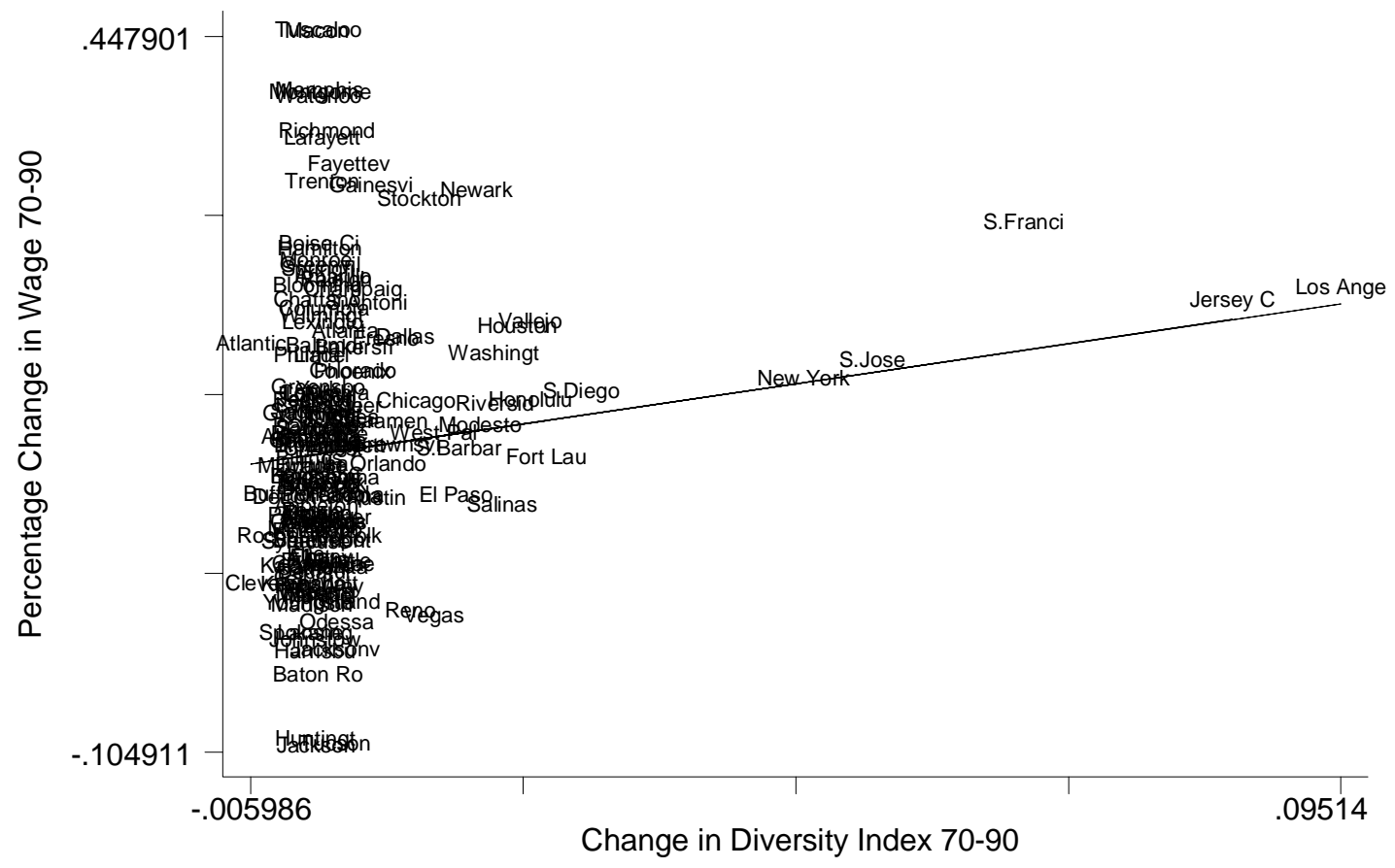

Figure 2 - Rents of US-born and Diversity

160 U.S. Metropolitan Areas

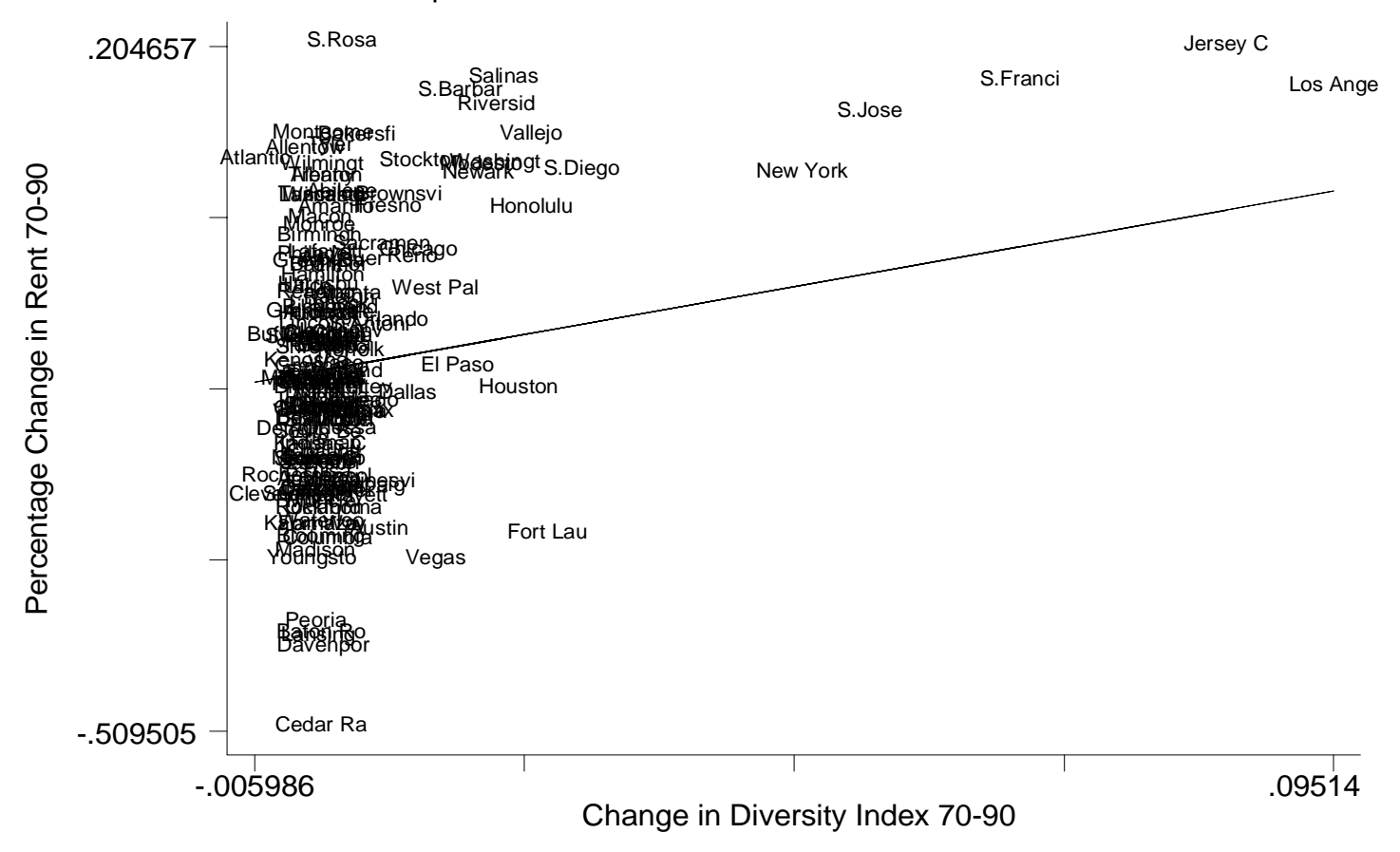


Figure 3 - The Spatial Equilibrium

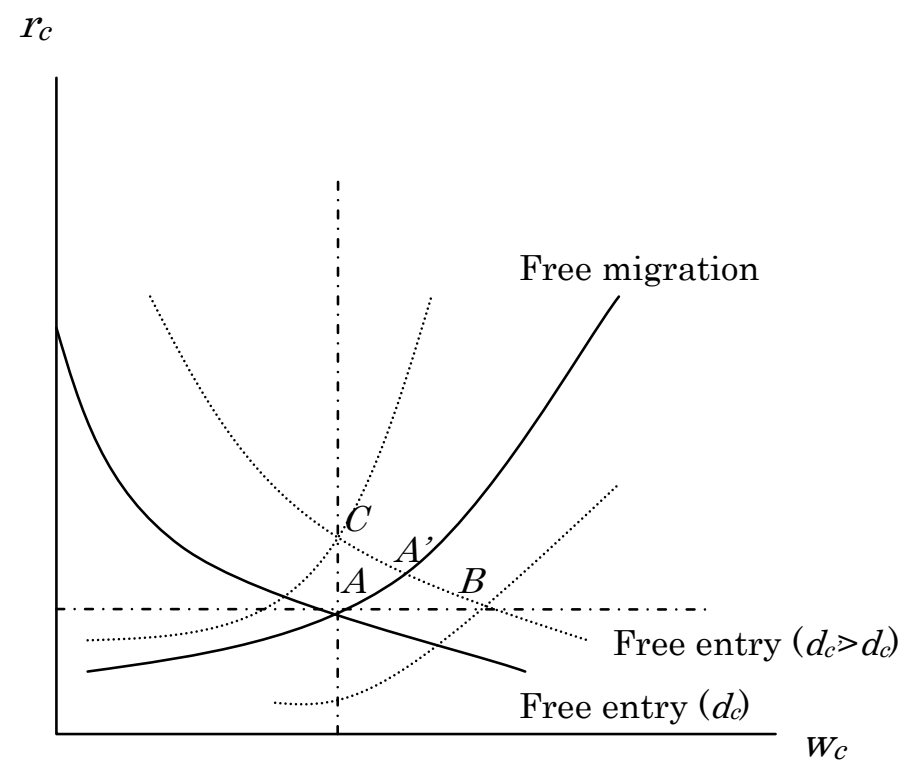

